\title{
Experimental Investigation of the Corrosion Behavior of Friction Stir Welded AZ61A Magnesium Alloy Welds under Salt Spray Corrosion Test and Galvanic Corrosion Test Using Response Surface Methodology
}

\author{
A. Dhanapal, ${ }^{1}$ S. Rajendra Boopathy, ${ }^{2}$ V. Balasubramanian, ${ }^{3}$ \\ K. Chidambaram, ${ }^{1}$ and A. R. Thoheer Zaman ${ }^{1}$ \\ ${ }^{1}$ Department of Mechanical Engineering, Sri Ramanujar Engineering College, Vandalur, Chennai, Tamil Nadu 600 048, India \\ ${ }^{2}$ Department of Mechanical Engineering, College of Engineering, Anna University, Chennai 600 025, India \\ ${ }^{3}$ Center for Materials Joining \& Research (CEMAJOR), Department of Manufacturing Engineering, Annamalai University, \\ Annamalai Nagar, Chidambaram 608 002, India
}

Correspondence should be addressed to A. Dhanapal; sridhanapal2010@gmail.com

Received 26 March 2013; Accepted 30 May 2013

Academic Editor: Chi Tat Kwok

Copyright (c) 2013 A. Dhanapal et al. This is an open access article distributed under the Creative Commons Attribution License, which permits unrestricted use, distribution, and reproduction in any medium, provided the original work is properly cited.

\begin{abstract}
Extruded Mg alloy plates of $6 \mathrm{~mm}$ thick of AZ61A grade were butt welded using advanced welding process and friction stir welding (FSW) processes. The specimens were exposed to salt spray conditions and immersion conditions to characterize their corrosion rates on the effect of $\mathrm{pH}$ value, chloride ion concentration, and corrosion time. In addition, an attempt was made to develop an empirical relationship to predict the corrosion rate of FSW welds in salt spray corrosion test and galvanic corrosion test using design of experiments. The corrosion morphology and the pit morphology were analyzed by optical microscopy, and the corrosion products were examined using scanning electron microscope and X-ray diffraction analysis. From this research work, it is found that, in both corrosion tests, the corrosion rate decreases with the increase in $\mathrm{pH}$ value, the decrease in chloride ion concentration, and a higher corrosion time. The results show the usage of the magnesium alloy for best environments and suitable applications from the aforementioned conditions. Also, it is found that AZ61A magnesium alloy welds possess low-corrosion rate and highercorrosion resistance in the galvanic corrosion test than in the salt spray corrosion test.
\end{abstract}

\section{Introduction}

Magnesium alloys have received extensive recognition due to their excellent physical properties, including light weight, high strength/weight ratio, high thermal conductivity, and good electromagnetic shielding characteristics; thus, become promising candidates to replace steel and aluminum alloys in many structural and mechanical applications due to their attractive mechanical and metallurgical properties $[1,2]$. The joining of magnesium components made from this alloy is, however, still limited. Unfortunately, conventional fusion welding of magnesium alloys often produces porosity and hot cracks in the welded joint. This deteriorates both the mechanical properties and corrosion resistance $[3,4]$. Hence, it will be of extreme benefit if a solid state joining process, that is, one which avoids bulk melting of the base materials, hot cracking, and porosity, can be developed and carried out for the joining of magnesium alloys.

FSW is a solid state welding process without emission of ration or dangerous fumes, and it avoids the formation of solidification defects like hot cracking and porosity. Moreover, it significantly improved the weld properties and had been extensively applied in the joining of magnesium alloys [5]. The application of $\mathrm{Mg}$ alloy in the structural members is still limited due to its conventional fusion welding resulting in many solidifications related problems such as hot cracking, porosity, alloy segregation, and partial melting zone. To overcome the previously said problems, FSW process had 
been used which is a solid state autogenous process, and, hence, there are no melting and solidification defects.

However, the corrosion resistance of the Mg-based alloys is generally inadequate due to the low-standard electrochemical potential $-2.37 \mathrm{~V}$ compared to the (SHE) standard hydrogen electrode [6], and this limits the range of applications for $\mathrm{Mg}$ and its alloys. Therefore, the study of corrosion behavior of magnesium alloys in active media, especially those containing aggressive ions, is crucial to the understanding the corrosion mechanisms and, hence, to improving the corrosion resistance under various service conditions. Salt spray testing is the main technique for corrosion studies, which was employed in this research in an effort to expose the AZ61 Mg alloy to an environment similar to that experienced by automotive engine blocks [7]. It is well known that $\mathrm{Mg}$ alloys are susceptible to corrosion such as pitting and stress cracking corrosion (SCC). Major studies show that the SCC susceptibility of Mg alloys is increased in solutions containing chloride [8,9]. The galvanic corrosion of magnesium using a (GCA) galvanic corrosion assembly which systematically investigates the influence of cathode materials the distance between anode and cathode, also for the anode/cathode area ratio. This study identified important effects such as the "alkalization," "passivation," poisoning, and shortcuts effect as well as the effectiveness of an insulating spacer in reduced galvanic corrosion [10]. It is well known that $\mathrm{Mg}$ alloys are susceptible to corrosion such as pitting and stress cracking corrosion (SCC). More studies show that the SCC susceptibility of Mg alloys is increased in solutions containing chloride $[11,12]$. The welding process inevitably causes changes in the original microstructure of the alloy due to welding thermal cycles. These microstructural changes can affect the localized corrosion behavior of the alloy [13]. Thus, the present study contributed towards the galvanic effect of the friction stir welded AZ61A magnesium alloy weld in contact with AZ61A Mg base metal couple. Galvanic corrosion, which is originally defined as the enhanced corrosion between two or more electrically connected metals. It is one of the most common forms of corrosion considering the real world engineering structures [14].

This research focused on comparing salt spray testing with galvanic corrosion testing, which are the two main techniques for the corrosion studies in an effort to expose the magnesium alloy and its welds to environments similar to those environments experienced for automotive and structural applications. Moreover, galvanic corrosion has never been investigated using identical couple electrodes; so in this present investigation, a new method is enhanced to predict the galvanic corrosion of FSW AZ61A Magnesium alloy. From the literature review, it was understood that most of the published information on corrosion behavior of $\mathrm{Mg}$ alloys was focused on general corrosion and pitting corrosion of unwelded base alloys. Very few investigations have been conducted so far on corrosion behavior of FSW joints of $\mathrm{Mg}$ alloys. The aim of this research is to investigate the occurrence of salt spray corrosion in FSW welds and galvanic corrosion in weld zone with parent alloy of AZ61A Mg alloy. Hence, the present investigation was carried out to study the effect of $\mathrm{pH}$ value, chloride ion concentration, and corrosion time

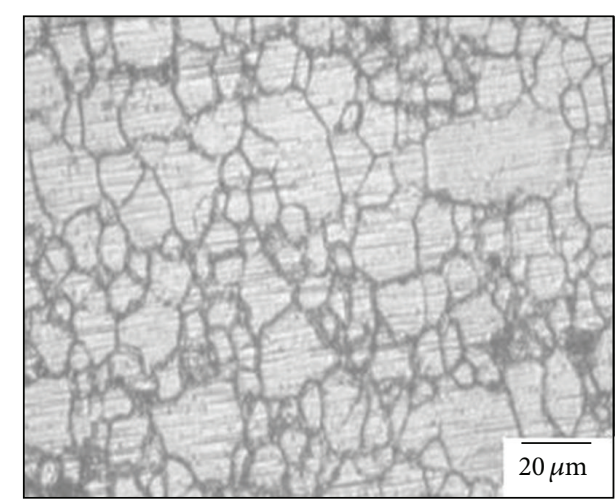

FIgURE 1: Optical micrograph of AZ61A base metal.

TABLE 1: (a) Chemical composition (wt\%) of AZ61A Mg alloy and (b) mechanical properties of AZ61A Mg alloy.

(a)

\begin{tabular}{lccc}
\hline $\mathrm{Al}$ & $\mathrm{Zn}$ & $\mathrm{Mn}$ & $\mathrm{Mg}$ \\
\hline 5.45 & 1.26 & 0.17 & Balance \\
\hline
\end{tabular}

(b)

\begin{tabular}{lccc}
\hline $\begin{array}{l}\text { Yield strength } \\
(\mathrm{MPa})\end{array}$ & $\begin{array}{c}\text { Ultimate tensile } \\
\text { strength } \\
(\mathrm{MPa})\end{array}$ & $\begin{array}{c}\text { Elongation } \\
(\%)\end{array}$ & $\begin{array}{c}\text { Vickers hardness } \\
\text { at 0.05 kg load } \\
(\mathrm{Hv})\end{array}$ \\
\hline 177 & 272 & 8.40 & 57 \\
\hline
\end{tabular}

on corrosion rate of AZ61A magnesium alloy welds and the galvanic couple.

\section{Experimental Procedure}

2.1. Test Materials. The material used in this study was an AZ61A magnesium alloy in the form of an extruded condition and supplied in plates of $6 \mathrm{~mm}$ thickness. The chemical composition and mechanical properties of the base metal are presented in Tables 1(a) and 1(b). The optical micrograph of the base metal is shown in Figure 1.

2.2. Fabricating the Joints and Preparing the Specimens. The plate was cut to a required size $(300 \mathrm{~mm} \times 150 \mathrm{~mm})$ by power hacksaw followed by milling. A square-butt joint configuration was prepared to fabricate the joints. The initial joint configuration was obtained by securing the plates in position using mechanical clamps. The direction of welding was normal to the extruded direction. Single pass welding procedure was followed to fabricate the joints. A nonconsumable tool made of high carbon steel was used to fabricate joints. An indigenously designed and developed computer numerical controlled friction stir welding machine (22 kW; 4000 RPM; $60 \mathrm{kN}$ ) was used to fabricate joints. The FSW parameters were optimized by conducting trial runs, and the welding conditions which produced defect-free joints were taken as optimized welding conditions. The optimized welding conditions used to fabricate the joints in this investigation are presented in Table 2. From the base metal and welded joints, 
TABLE 2: Optimized welding conditions and process parameters used to fabricate the joints.

\begin{tabular}{lccccrr}
\hline $\begin{array}{l}\text { Rotational } \\
\text { speed }(\mathrm{rpm})\end{array}$ & $\begin{array}{c}\text { Welding speed } \\
(\mathrm{mm} / \mathrm{min})\end{array}$ & $\begin{array}{c}\text { Axial force } \\
(\mathrm{kN})\end{array}$ & $\begin{array}{c}\text { Tool shoulder diameter } \\
(\mathrm{mm})\end{array}$ & $\begin{array}{c}\text { Pin diameter } \\
(\mathrm{mm})\end{array}$ & $\begin{array}{c}\text { Pin length } \\
(\mathrm{mm})\end{array}$ & $\begin{array}{c}\text { Pin profile } \\
1000\end{array}$ \\
\hline & 35 & 3 & 18 & 6 & 5 & $\begin{array}{c}\text { Left hand thread } \\
\text { of } 1 \mathrm{~mm} \text { pitch }\end{array}$ \\
\hline
\end{tabular}

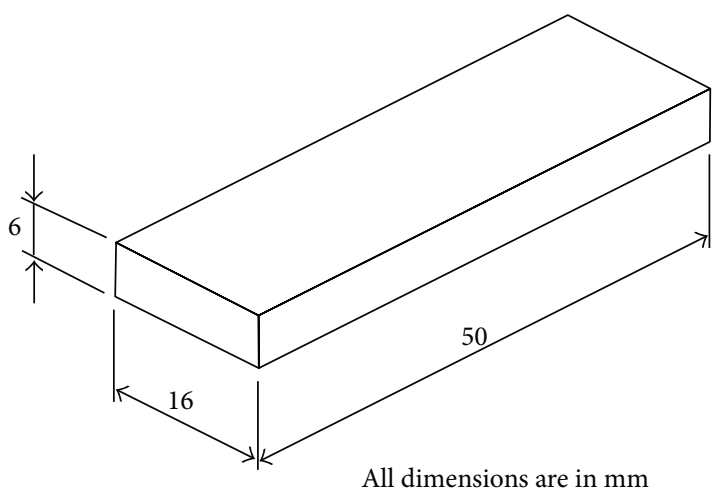

FIGURE 2: Dimensions of corrosion test specimen.

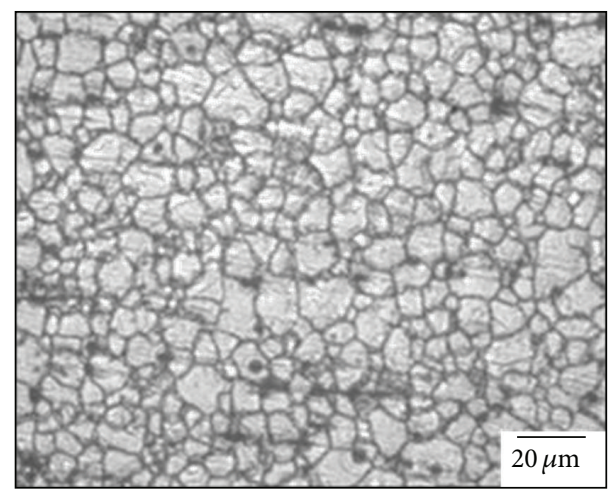

FIgURE 3: Microstructure of friction stir welded stir zone before the corrosion test.

the corrosion test specimens were sliced to the dimensions of $50 \mathrm{~mm} \times 16 \mathrm{~mm} \times 6 \mathrm{~mm}$ shown in Figure 2. The specimens were ground with $500^{\#}, 800^{\#}, 1200^{\#}, 1500^{\#}$ grit $\mathrm{SiC}$ paper. Finally, it was cleaned with acetone and washed in distilled water then dried by warm flowing air. The optical micrograph of the stir zone of the FSW joint of AZ61A magnesium alloy is shown in Figure 3.

2.3. Finding the Limits of Corrosion Test Parameters. From the literature $[15,16]$, the predominant factors that have a greater influence on corrosion behavior of AZ61A magnesium alloy are identified. They are (i) $\mathrm{pH}$ value of the solution, (ii) exposure time, and (iii) chloride ion concentration. Large numbers of trial experiments were conducted to identify the feasible testing conditions using friction stir welded AZ61A magnesium alloy joints under galvanic test conditions. The following inferences are obtained.

(1) If the $\mathrm{pH}$ value of the solution was less than 3 therefore, the change in chloride ion concentration did not considerably affect the corrosion.
(2) If the $\mathrm{pH}$ value was between 3 and 11 therefore, there were inhibition of the corrosion process and stabilization of the protective layer.

(3) If the $\mathrm{pH}$ value was greater than 11 therefore, blocking of further corrosion by the active centers of the partially protective layer.

(4) If the chloride ion concentration was less than $0.2 \mathrm{M}$ therefore, the visible corrosion did not occur in the experimental period.

(5) If the chloride ion concentration was between $0.2 \mathrm{M}$ and $1 \mathrm{M}$ therefore, there was a reasonable fluctuation in the corrosion rate.

(6) If the chloride ion concentration was greater than $1 \mathrm{M}$ therefore, the rise in corrosion rate slightly decreased a little.

(7) If the exposure time was less than an hour therefore, the surface would be completely covered with thick and rough corrosion products.

(8) If the exposure time was between 1 and 9 hours therefore, the tracks of the corrosion could be predicted.

(9) If the exposure time was greater than 9 hours therefore, the tracks of corrosion film were difficult to identify.

2.4. Developing the Experimental Design Matrix. Owing to a wide range of factors, the use of three factors and central composite rotatable design matrix was chosen to minimize the number of experiments. The assay conditions for the reaction parameters were taken at zero level (center point) and one level $(+1)$ and (1). The design was extended up to a $\pm \alpha$ (axial point) of 1.68. The center values for variables were carried out at least six times for the estimation of error and single runs for each of the other combinations; twenty runs were done in a totally random order. The design would consist of the eight corner points of the $2^{3}$ cube, the six star points, and $m$ center points. The star points would have $a=$ $8^{\wedge}(1 / 4)=1.682$. Design matrix consisting of 20 sets of coded conditions (comprising a full replication three factorial of 8 points, six corner points, and six center points) was chosen in this investigation. Table 3 represents the ranges of factors considered, and Table 4 shows the 20 sets of coded and actual values used to conduct the experiments. For the convenience of recording and processing experimental data, the upper and lower levels of the factors were coded here as +1.682 and -1.682 , respectively. The coded values of any intermediate values could be calculated using the following relationship:

$$
X_{i}=\frac{1.682\left[2 X-\left(X_{\max }-X_{\min }\right)\right]}{\left(X_{\max }-X_{\min }\right)},
$$


TABLE 3: Important factors and their levels.

\begin{tabular}{|c|c|c|c|c|c|c|c|c|}
\hline \multirow{2}{*}{ S. no. } & \multirow{2}{*}{ Factor } & \multirow{2}{*}{ Unit } & \multirow{2}{*}{ Notation } & \multicolumn{5}{|c|}{ Levels } \\
\hline & & & & -1.682 & -1 & 0 & +1 & +1.682 \\
\hline 1 & $\mathrm{pH}$ value & & $P$ & 3 & 4.62 & 7 & 9.38 & 11 \\
\hline 2 & Corrosion time & Hours (h) & $T$ & 1 & 2.62 & 5 & 7.38 & 9 \\
\hline 3 & $\mathrm{Cl}^{-}$concentration & Mole (M) & C & 0.2 & 0.36 & 0.6 & 0.84 & 1 \\
\hline
\end{tabular}

TABLE 4: Design matrix and experimental results.

\begin{tabular}{|c|c|c|c|c|c|c|c|c|}
\hline \multirow{2}{*}{ EX. no. } & \multicolumn{3}{|c|}{ Coded values } & \multicolumn{3}{|c|}{ Actual values } & \multirow{2}{*}{$\begin{array}{l}\text { Corrosion rate (salt } \\
\text { spray tests) }(\mathrm{mm} / \mathrm{yr})\end{array}$} & \multirow{2}{*}{$\begin{array}{l}\text { Corrosion rate (galvanic } \\
\text { corrosion tests) }(\mathrm{mm} / \mathrm{yr})\end{array}$} \\
\hline & $\begin{array}{l}\mathrm{pH} \\
(P)\end{array}$ & $\begin{array}{l}\text { Time } \\
(T)\end{array}$ & $\begin{array}{l}\text { Conc. } \\
(C)\end{array}$ & $\begin{array}{l}\mathrm{pH} \\
(P)\end{array}$ & $\begin{array}{c}\text { Time } \\
(T) \\
\text { (hour) }\end{array}$ & $\begin{array}{l}\text { Conc. } \\
(C) \\
\text { (Mole) }\end{array}$ & & \\
\hline 1 & -1 & -1 & -1 & 4.62 & 2.62 & 0.36 & $14.62(0.11)$ & $0.0397(0.16)$ \\
\hline 2 & +1 & -1 & -1 & 9.38 & 2.62 & 0.36 & $10.23(0.56)$ & $0.0254(0.13)$ \\
\hline 3 & -1 & +1 & -1 & 4.62 & 7.38 & 0.36 & $11.89(0.21)$ & $0.0340(0.20)$ \\
\hline 4 & +1 & +1 & -1 & 9.38 & 7.38 & 0.36 & $8.99(0.18)$ & $0.0111(0.18)$ \\
\hline 5 & -1 & -1 & +1 & 4.62 & 2.62 & 0.84 & $15.82(0.16)$ & $0.0456(0.14)$ \\
\hline 6 & +1 & -1 & +1 & 9.38 & 2.62 & 0.84 & $11.31(0.1)$ & $0.0425(0.1)$ \\
\hline 7 & -1 & +1 & +1 & 4.62 & 7.38 & 0.84 & $12.92(0.26)$ & $0.0519(0.52)$ \\
\hline 8 & +1 & +1 & +1 & 9.38 & 7.38 & 0.84 & $10.75(0.05)$ & $0.0376(0.05)$ \\
\hline 9 & -1.682 & 0 & 0 & 3 & 5 & 0.60 & $17.96(0.26)$ & $0.0612(0.08)$ \\
\hline 10 & +1.682 & 0 & 0 & 11 & 5 & 0.60 & $6.88(0.41)$ & $0.0267(0.11)$ \\
\hline 11 & 0 & -1.682 & 0 & 7 & 1 & 0.60 & $11.23(0.56)$ & $0.0598(0.07)$ \\
\hline 12 & 0 & +1.682 & 0 & 7 & 9 & 0.60 & $8.51(0.42)$ & $0.0282(0.11)$ \\
\hline 13 & 0 & 0 & -1.682 & 7 & 5 & 0.20 & $6.66(0.23)$ & $0.0184(0.05)$ \\
\hline 14 & 0 & 0 & +1.682 & 7 & 5 & 1 & $15.28(0.4)$ & $0.0534(0.08)$ \\
\hline 15 & 0 & 0 & 0 & 7 & 5 & 0.60 & $9.89(0.36)$ & $0.0432(0.03)$ \\
\hline 16 & 0 & 0 & 0 & 7 & 5 & 0.60 & $8.56(0.02)$ & $0.0365(0.02)$ \\
\hline 17 & 0 & 0 & 0 & 7 & 5 & 0.60 & $9.79(0.03)$ & $0.0370(0.21)$ \\
\hline 18 & 0 & 0 & 0 & 7 & 5 & 0.60 & $9.97(0.05)$ & $0.0377(0.24)$ \\
\hline 19 & 0 & 0 & 0 & 7 & 5 & 0.60 & $8.93(0.04)$ & $0.0379(0.38)$ \\
\hline 20 & 0 & 0 & 0 & 7 & 5 & 0.60 & $9.62(0.09)$ & $0.0381(0.12)$ \\
\hline
\end{tabular}

The values presented in brackets are the standard deviation.

where $X_{i}$ is the required code values of a variable $X$, and $X$ is any values of the variable from $X_{\min }$ to $X_{\max } ; X_{\min }$ is the lower level of the variable, and $X_{\max }$ is the upper level of the variable.

2.5. Salt Spray Corrosion Test (Recording the Response). Solutions of $\mathrm{NaCl}$ with concentrations of $0.2 \mathrm{M}, 0.361 \mathrm{M}$, $0.6 \mathrm{M}, 0.838 \mathrm{M}$, and $1 \mathrm{M}$ were prepared. The $\mathrm{pH}$ values of the solutions were maintained as $\mathrm{pH} 3, \mathrm{pH} 4.619, \mathrm{pH}$, $\mathrm{pH} 9.38$, and $\mathrm{pH} 11$ with concentrated $\mathrm{HCl}$ and $\mathrm{NaOH}$, respectively. The $\mathrm{pH}$ value was measured using a digital $\mathrm{pH}$ meter. The test method consists of exposing the specimens in a salt spray chamber as per ASTM B 117 standards and evaluating the corrosion tested specimen with the method as per ASTM G1-03. Basically, the salt spray test procedure involves the spraying of a salt solution onto the samples being tested. This was done inside a temperature controlled chamber. The glass racks were contained in the salt fog chamber $\left(3^{\prime \prime}\right.$ high, $3^{\prime \prime}$ deep, and $5^{\prime \prime}$ wide). The samples under test were inserted into the chamber, following which the salt-containing solution was sprayed as a very fine fog mist over the samples. $\mathrm{NaCl}$ in tapped water was pumped from a reservoir to spray nozzles. The solution was mixed with humidified compressed air at the nozzle, and this compressed air and atomized the $\mathrm{NaCl}$ solution into a fog at the nozzle. Heaters were maintained at $35^{\circ} \mathrm{C}$ cabinet temperature. Within the chamber, the samples were rotated frequently so that all samples were exposed uniformly to the salt spray mist. Since the spray was continuous, the samples were continuously wet and therefore, uniformly subjected to corrosion. The corrosion rate of the friction stir welded AZ61A alloy specimen was estimated by weight loss measurement. The original weight $\left(w_{o}\right)$ of the specimen was recorded, and then the specimen was sprayed with the solution of $\mathrm{NaCl}$ for different spraying times of $1,2.62,5,7.38$, and 9 hours. The corrosion products were removed by immersing the specimens for one minute in a solution prepared by using 50 gm chromium trioxide $\left(\mathrm{CrO}_{3}\right)$, 


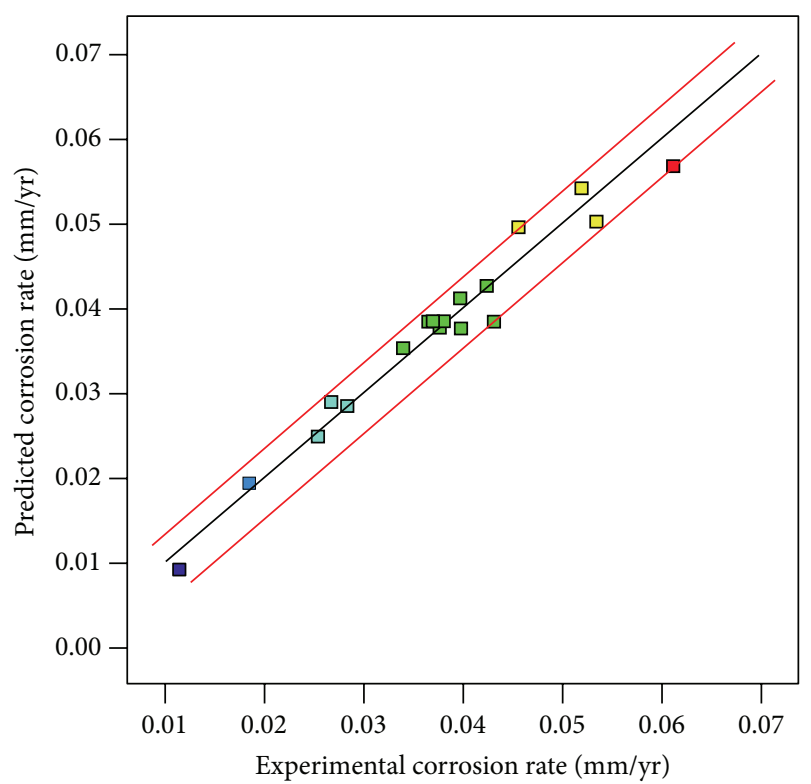

FIGURE 4: Correlation graph for response (salt spray corrosion test).

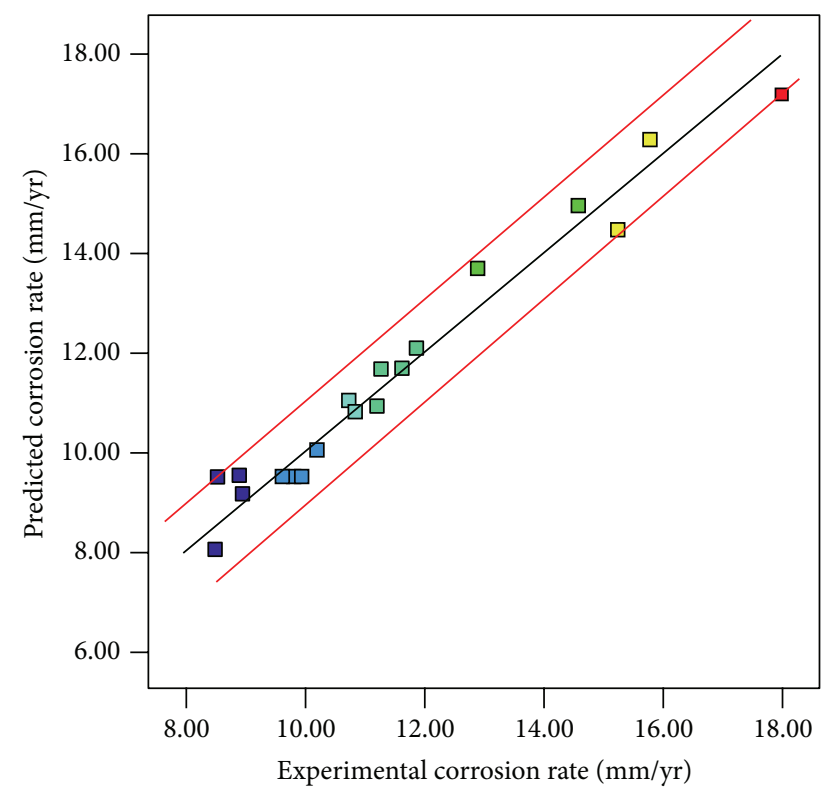

FIGURE 5: Correlation graph for response (galvanic corrosion test).

$2.5 \mathrm{gm}$ silver nitrate $\left(\mathrm{AgNO}_{3}\right)$, and $5 \mathrm{gm}$ barium nitrate $\left(\mathrm{Ba}\left(\mathrm{NO}_{3}\right)_{2}\right)$ in $250 \mathrm{~mL}$ distilled water. Finally, the specimens were washed with distilled water, dried, and weighed again to obtain the final weight $\left(w_{1}\right)$. The weight loss $(w)$ can be measured using the following relation:

$$
w=\left(w_{o}-w_{1}\right)
$$

where $w$ is weight loss in grams, $w_{o}$ is original weight before test in grams, and $w_{1}$ is final weight after test in grams.
The corrosion rate of FSW joints of AZ61A was calculated by using the following equation as per the ASTM standards B117:

$$
\text { corrosion rate }(\mathrm{mm} / \text { year })=\frac{8.76 \times 10^{4} \times w}{A \times D \times T},
$$

where $w$ is weight loss in grams, $A$ is surface area of the specimen in $\mathrm{cm}^{2}, D$ is density of the material $\left(1.72 \mathrm{gm} / \mathrm{cm}^{3}\right)$, and $T$ is spraying time in hours.

2.6. Galvanic Corrosion Test (Recording the Response). The test method consisted of exposing the specimens in a specially designed apparatus as per ASTM G 82-98 standards and evaluating the corrosion tested specimen with the method as per ASTM G 102-89. The galvanic samples were prepared in the following way. A saturated calomel electrode and graphite electrode were used as the reference and auxiliary electrode, respectively. The working electrodes were the friction stir welded AZ61A magnesium alloy welds coupled with AZ61A magnesium alloy base metal. An electrical contact was made between the galvanic couple, where a Teflon insulation of the same thickness was inserted between the electrodes to avoid the direct contact between the electrodes. The galvanic couple was immersed in $\mathrm{NaCl}$ solution with different $\mathrm{pH}$ and chloride ion concentration for different immersion times of $1,2.62,5,7.38$, and 9 hours. When the mixed potential theory was applied to the individual reactions, the uncoupled corrosion rates were $i_{\text {corr }}(\mathrm{A})$ for AZ61A magnesium alloy base metal and $i_{\text {corr }}$ (B) for AZ61A friction stir welds. When equal areas of AZ61A Mg base metal and AZ61A friction stir welds were coupled, the resultant mixed potential of the system $E_{\text {corr }}(\mathrm{AB})$ was at the intersection where the total oxidation rate equals the total reduction rate. The rate of oxidation of the individual coupled metals was such that the base metal corroded at a reduced rate $i_{\text {corr }}(\mathrm{A})$, and AZ61A friction stir welds corroded at an increased rate $I_{\text {corr }}(\mathrm{B})$. Hence, the AZ61A friction stir weld acts as an anode, and AZ61A base alloy acts as a cathode. Half-cell reactions were carried out constituting a single cell. Thus, the current $i_{\text {corr }}$ $(\mathrm{AB})$ was the galvanic current which can be measured by a zero resistance ammeter (ZRA). Free corrosion potential of both metals was found individually and from the potential difference; FSW AZ61A magnesium alloy was considered to be an anode, because of its more negative potential than AZ61 base alloy, where the latter was the cathode. Corrosion current values may be obtained from the ZRA measurements. The corrosion rate can be calculated using Faraday's Law in terms of penetration rates as follows:

$$
\text { corrosion rate }(\mathrm{mm} / \mathrm{yr})=\frac{K \times I_{\text {corr }} \times \mathrm{EW}}{\rho},
$$

where $K$ is corrosion constant ( $K$ is 0.00327 if corrosion rate in $(\mathrm{mm} / \mathrm{yr})), I_{\text {corr }}$ is current density in $\mathrm{mA} / \mathrm{cm}^{2}, \mathrm{EW}$ is equivalent weight of the alloy, and $\rho$ is density of the FSW AZ61A alloy $\left(1.72 \mathrm{gm} / \mathrm{cm}^{3}\right)$.

2.7. Metallography. Microstructural analysis of the corroded specimens was carried out using a light optical microscope 


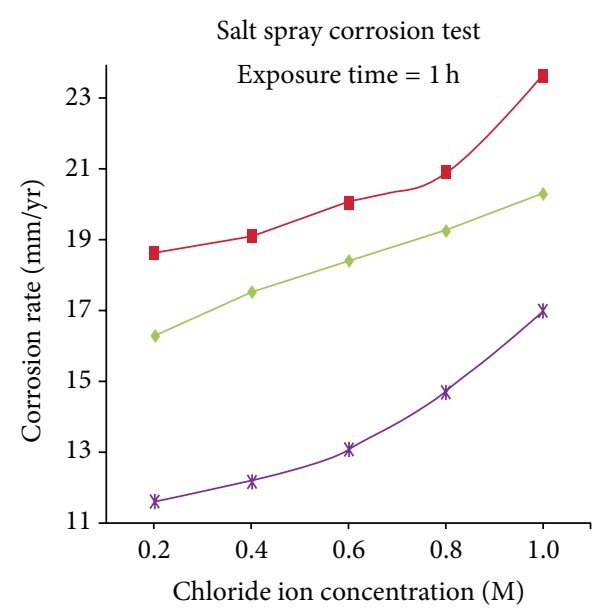

(a)

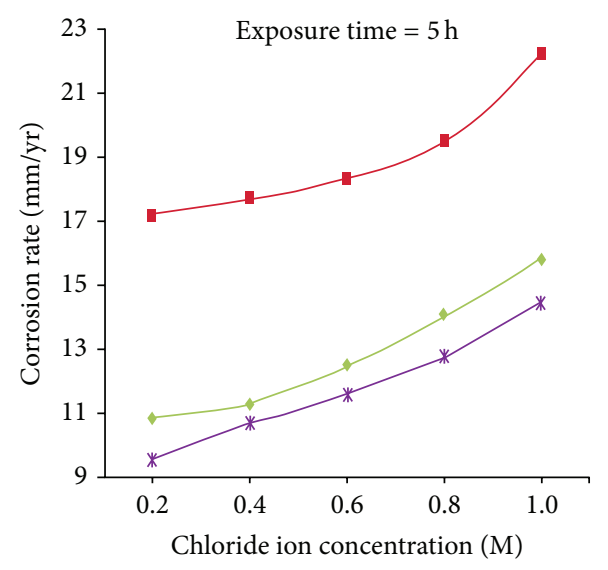

(c)

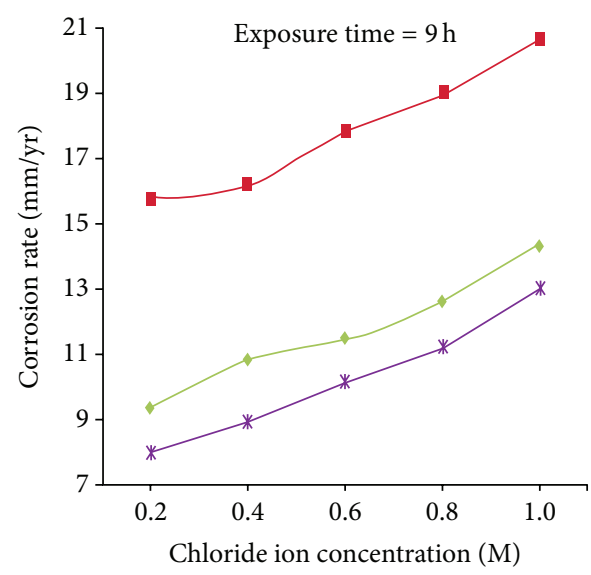

$\rightarrow \mathrm{pH}=3$

$\rightarrow \mathrm{pH}=7$

* $\mathrm{pH}=11$

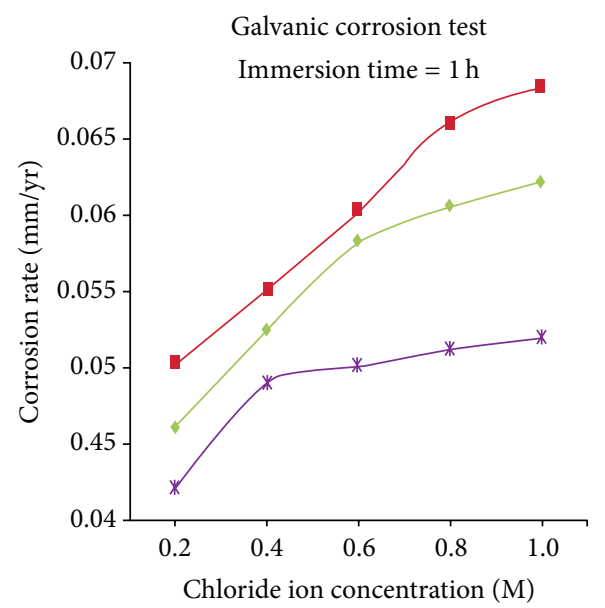

(b)

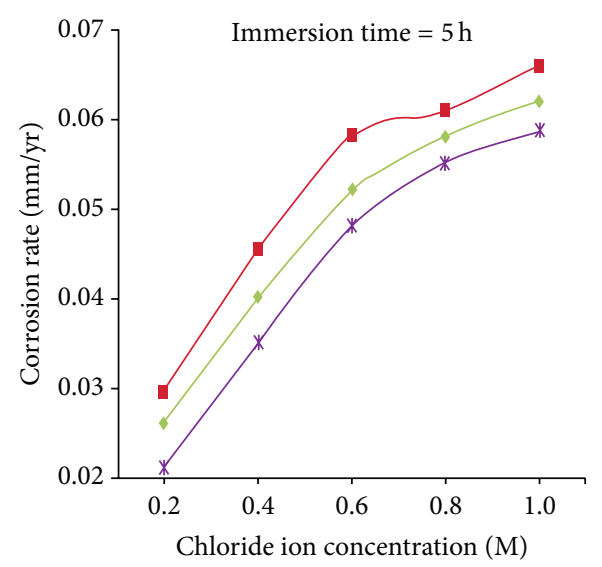

(d)

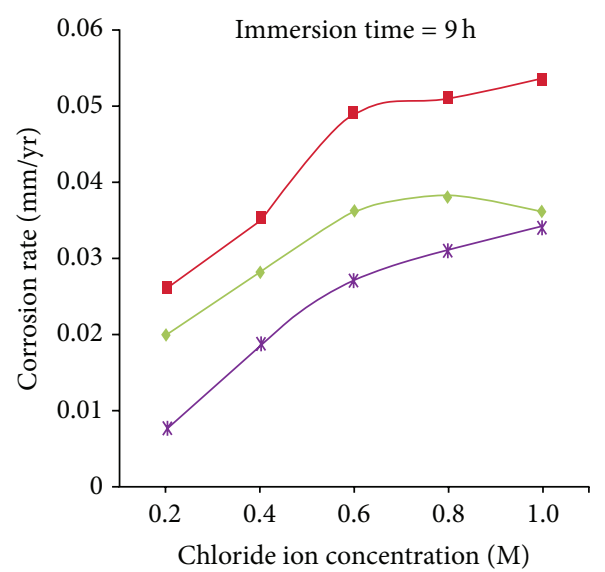

$-\mathrm{pH}=3$

$\rightarrow \mathrm{pH}=7$

* $\mathrm{pH}=11$

(e)

FIGURE 6: Effect of $\mathrm{pH}$ value on corrosion rate. 


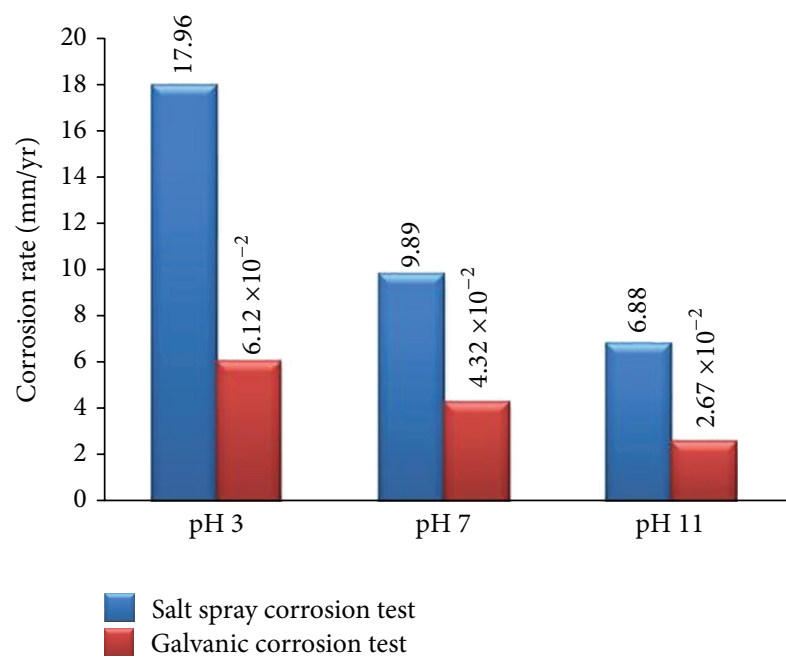

FIGURE 7: Comparative estimation of corrosion rate with respect to $\mathrm{pH}$ value.

(Union Optics, Japan; model: Versamet-3) incorporated with an image analyzing software (Clemex-vision). The exposed specimen surface was prepared for the microexamination in the "as polished" conditions. The corrosion test specimens were polished in disc-polishing machine with minor polishing, and the surface was observed at 200x magnification. The corrosion products were analyzed by SEM-EDX and XRD analysis.

\section{Developing an Empirical Relationship}

The response surface methodology (RSM) approach was adopted in this study because of its following advantages: (1) the ability to evaluate the effects of interactions between tested parameters and (2) the benefit of limiting the number of actual experiments to be carried out, in comparison to a classical approach for the same number of estimated parameters [17-20]. In the present investigation, to correlate the potentiodynamic polarization test parameters and the corrosion rate of AZ61A welds, a second-order quadratic model was developed. The response (corrosion rate of AZ61A welds) is a function of $\mathrm{pH}$ values $(P)$, exposure time $(T)$, and chloride ion concentration $(C)$, and it could be expressed as

$$
\text { corrosion rate }=f(P, T, C) .
$$

In order to study the combined effects of these parameters, experiments were conducted at different combinations using statistically designed experiments. The empirical relationship must include the main and interaction effects of all factors and hence the selected polynomials are expressed as follows:

$$
Y=b_{o}+\sum b_{i} x_{i}+\sum b_{i i} x_{i}^{2}+\sum b_{i j} x_{i} x_{j}
$$

For three factors, the selected polynomial could be expressed as

$$
\begin{aligned}
\text { corrosion rate }=\{ & \left\{b_{0}+b_{1}(P)+b_{2}(T)+b_{3}(C)\right. \\
& +b_{11}\left(P^{2}\right)+b_{22}\left(T^{2}\right)
\end{aligned}
$$

$$
\begin{aligned}
& +b_{33}\left(C^{2}\right)+b_{12}(P T) \\
& \left.+b_{13}(P C)+b_{23}(T C)\right\},
\end{aligned}
$$

where $b_{0}$ is the average of responses (corrosion rate), and $b_{1}, b_{2}, b_{3} \ldots b_{11}, b_{12}, b_{13} \ldots b_{22}, b_{23}, b_{33}$ are the coefficients that depend on their respective main and interaction factors, which are calculated using the expression given as follows:

$$
B_{i}=\frac{\sum\left(X_{i}, Y_{i}\right)}{n},
$$

where " $I$ " varies from 1 to $n$, in which $X_{i}$ is the corresponding coded value of a factor, $Y_{i}$ is the corresponding response output value (corrosion rate) obtained from the experiment, and " $n$ " is the total number of combinations considered. All the coefficients were obtained applying central composite rotatable design matrix including the Design Expert statistical software package. After determining the significant coefficients (at 95\% confidence level), the final relationship was developed including only these coefficients. The final empirical relationship obtained by the above procedure to estimate the corrosion rate of friction stir welds of AZ61A magnesium alloy is given as follows.

Salt spray corrosion test,

$$
\begin{aligned}
\text { corrosion rate }= & \{9.48-1.89(P)-0.88(T)+0.82(C) \\
& \left.+1.60\left(P^{2}\right)+1.27\left(C^{2}\right)\right\} \mathrm{mm} / \mathrm{yr}
\end{aligned}
$$

Galvanic corrosion test,

$$
\begin{aligned}
\text { corrosion rate }=\{ & 0.056-7.33 \times 10^{-3}(P) \\
& +2.75 \times 10^{-3}(T)+0.016(C) \\
& -4.25 \times 10^{-3}(P T)+4.26 \times 10^{-3}(P C) \\
& +4.6 \times 10^{-3}(T C) \\
& \left.-3.74 \times 10^{-4}\left(T^{2}\right)\right\} \mathrm{mm} / \mathrm{yr} .
\end{aligned}
$$

3.1. Checking the Adequacy of the Model Salt Spray Testing. The Analysis of Variance (ANOVA) technique was used to find the significant main and interaction factors. The results of the second-order response surface model fitting in the form of Analysis of Variance (ANOVA) are given in Table 5. The determination coefficient $\left(r^{2}\right)$ indicated the goodness of fit for the model. The model $F$ value of 31.30 implies the model is significant. There is only a $0.01 \%$ chance that a "model $F$ value" this large could occur due to noise. Values of "Prob $>F$ " less than 0.0500 indicate that model terms are significant. In this case $P, T, C$, $P^{2}$, and $C^{2}$ are significant model terms. Values greater than 0.1000 indicate that the model terms are not significant. If there are many insignificant model terms (not counting those required to support hierarchy), model reduction may improve the model. The "lack of fit $F$ value" of 1.69 


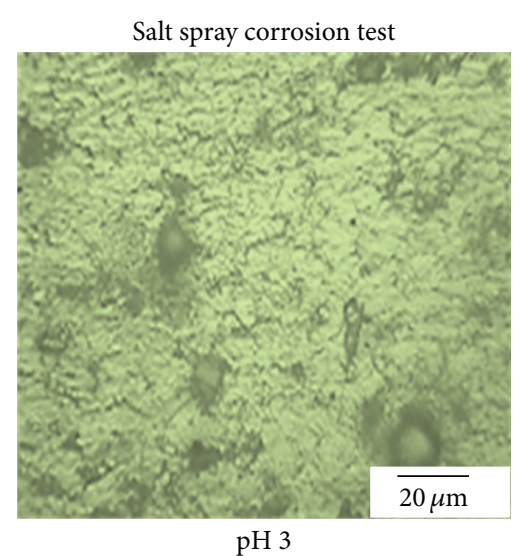

(a)

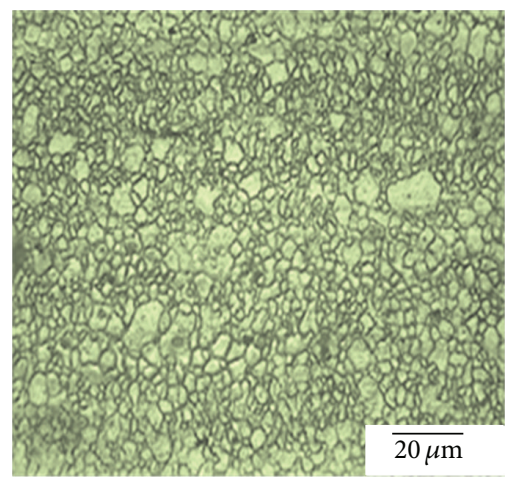

$\mathrm{pH} 7$

(c)

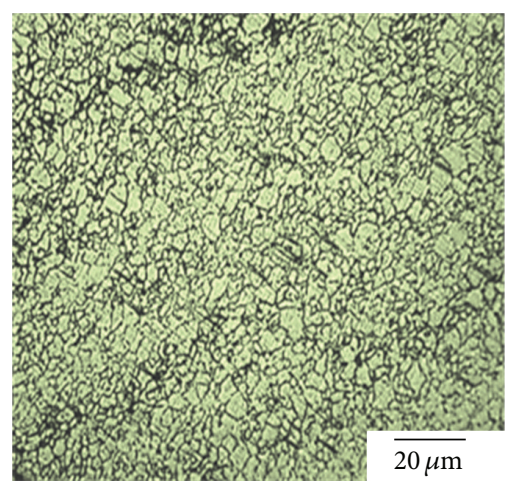

$\mathrm{pH} 11$

(e)

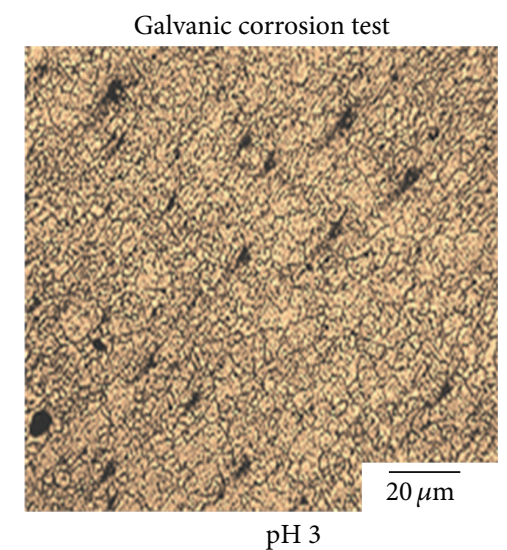

(b)

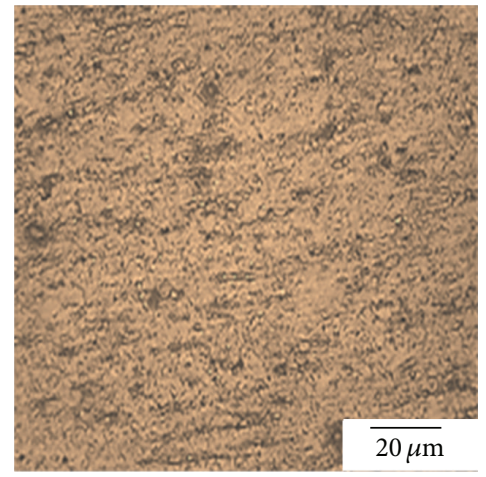

$\mathrm{pH} 7$

(d)

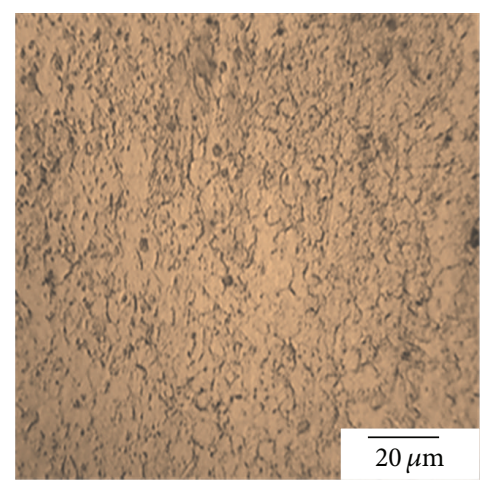

$\mathrm{pH} 11$

(f)

Figure 8: Effect of $\mathrm{pH}$ on pit morphology.

implies that the lack of fit is not significant relative to the pure error. There is a $28.93 \%$ chance that a "lack of fit $F$ value" this large could occur due to noise. Nonsignificant lack of fit is good. The "Pred R-Squared" of 0.8176 is in reasonable agreement with the "Adj $R$-Squared" of 0.9349 . "Adeq Precision" measures the signal to noise ratio. $P$ ratio greater than 4 is desirable. Our ratio of 19.440 indicates an adequate signal. All of this indicated an excellent suitability of the regression model. Each of the observed values compared with the experimental values are shown in Figure 4.
3.2. Checking the Adequacy of the Model Galvanic Corrosion Testing. The Analysis of Variance (ANOVA) technique was used to find the significant main and interaction factors. The results of second-order response surface model fitting in the form of Analysis of Variance (ANOVA) are given in Table 6. The determination coefficient $\left(r^{2}\right)$ indicated the goodness of fit for the model. The model $F$ value of $27.66 \mathrm{implies}$ the model is significant. There is only a $0.01 \%$ chance that a "model $F$ value" this large could occur due to noise. Values of "Prob > $F$ " less than 0.0500 indicate that model terms are significant. 


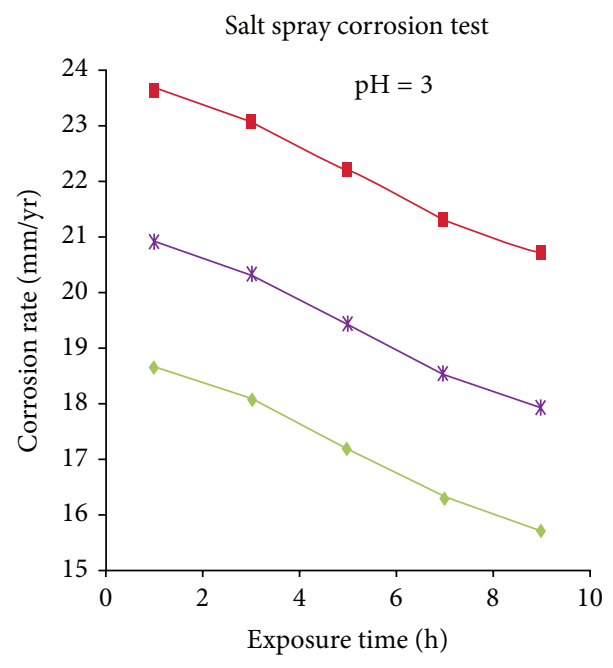

(a)

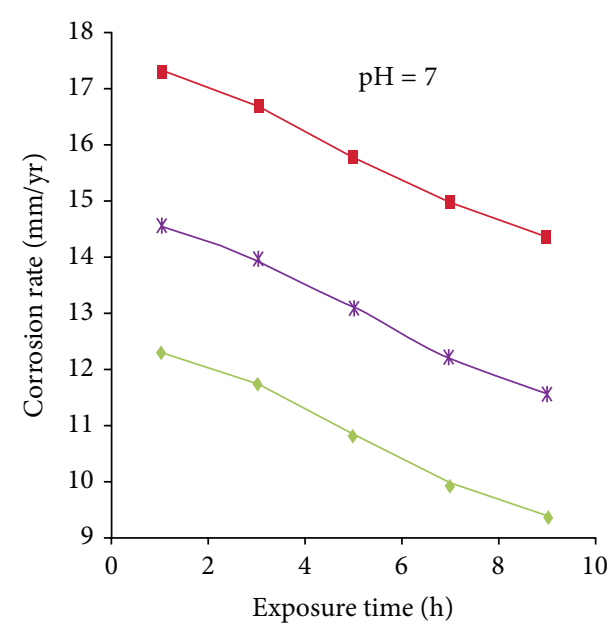

(c)

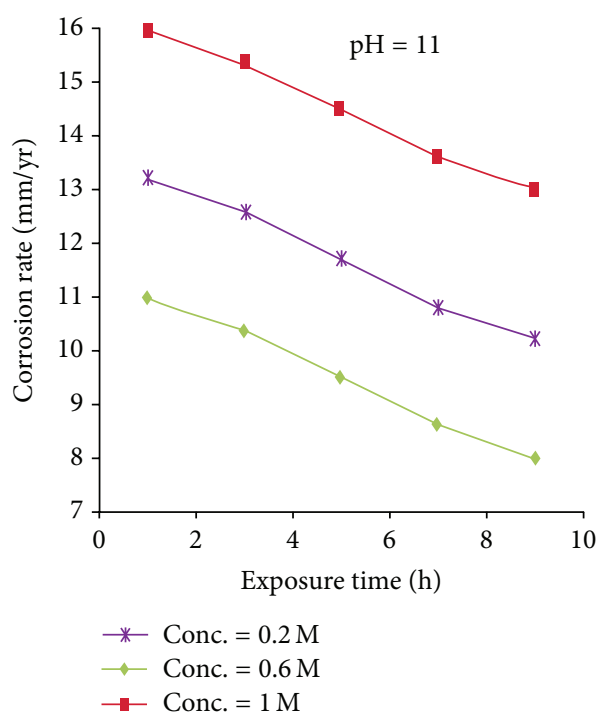

(e)

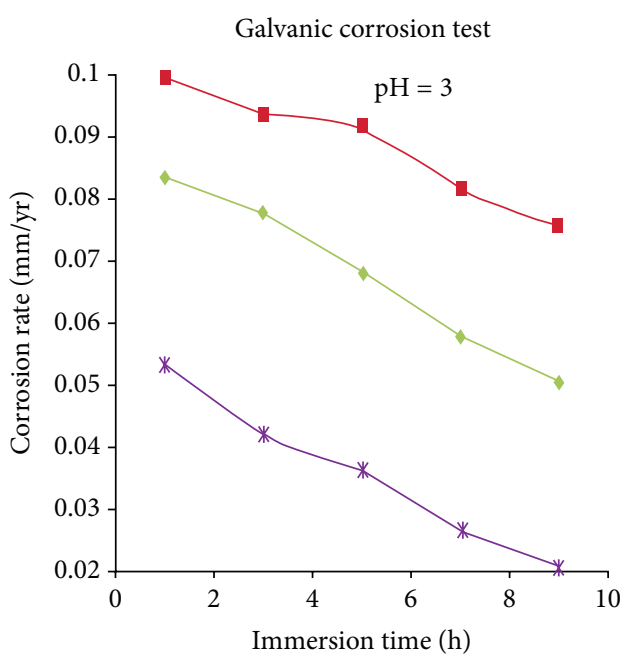

(b)

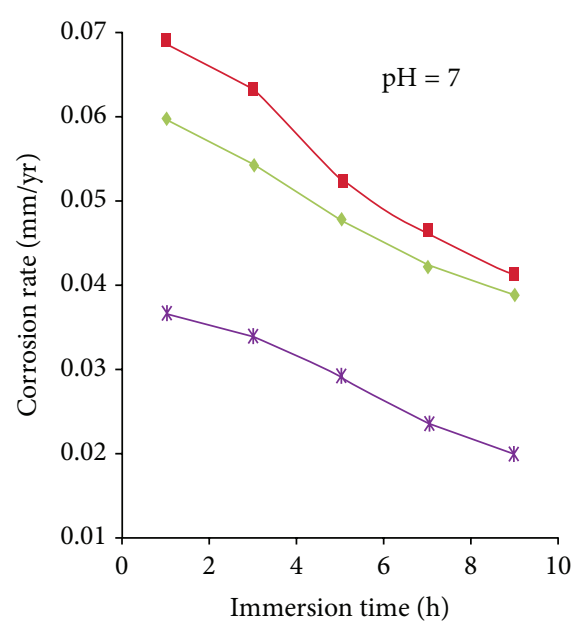

(d)

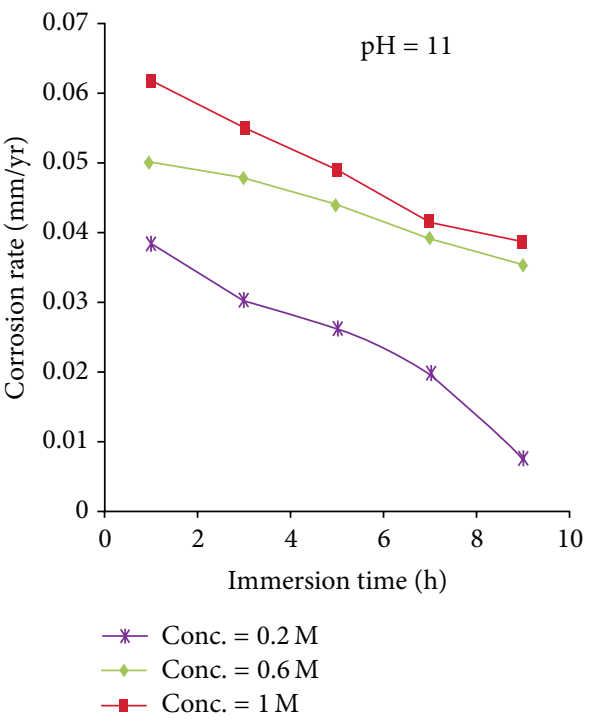

(f)

FIGURE 9: Effect of chloride ion concentration on corrosion rate. 
TABLE 5: ANOVA test results for salt spray corrosion test.

\begin{tabular}{lccccc}
\hline Source & Sum of squares & $\mathrm{df}$ & Mean square & $F$ value & $P$ value \\
\hline Model & 126.60 & 9 & 14.07 & 31.30 & $<0.0001$ \\
$P$ & 49.03 & 1 & 49.03 & 109.11 & $<0.0001$ \\
$T$ & 10.55 & 1 & 10.55 & 23.48 & 0.0007 \\
$C$ & 9.12 & 1 & 9.12 & 20.29 & 0.0011 \\
$P T$ & 1.83 & 1 & 1.83 & 4.08 & 0.0710 \\
$P C$ & 0.047 & 1 & 0.047 & 0.10 & 0.7543 \\
$T C$ & 0.033 & 1 & 0.033 & 0.072 & 0.7934 \\
$P^{2}$ & 37.07 & 1 & 37.07 & 82.48 & $<0.0001$ \\
$T^{2}$ & $3.4 E-004$ & 1 & $3.4 E-004$ & $7.6 E-004$ & 0.9785 \\
$C^{2}$ & 23.17 & 1 & 23.17 & 51.55 & $<0.0001$ \\
Residual & 4.49 & 10 & 0.45 & & 0.2893 \\
Lack of fit & 2.82 & 5 & 0.53 & 1.69 & Not significant \\
Pure error & 1.67 & 5 & 0.33 & & \\
Cor total & 131.09 & 19 & & & \\
\hline
\end{tabular}

TABLE 6: ANOVA test results for galvanic corrosion test.

\begin{tabular}{lccccc}
\hline Source & Sum of squares & $\mathrm{df}$ & Mean square & $F$ value & $P$ value \\
\hline Model & $2.472 E-003$ & 9 & $2.472 E-003$ & 27.66 & $<0.0001$ \\
$P$ & $9.229 E-004$ & 1 & $9.229 E-004$ & 92.93 & $<0.0001$ \\
$T$ & $1.057 E-004$ & 1 & $1.057 E-004$ & 10.64 & 0.0085 \\
$C$ & $1.163 E-004$ & 1 & $1.163 E-004$ & 117.12 & $<0.0001$ \\
$P T$ & $4.642 E-005$ & 1 & $4.642 E-004$ & 4.67 & 0.0559 \\
$P C$ & $4.700 E-005$ & 1 & $4.700 E-005$ & 4.73 & 0.0547 \\
$T C$ & $5.634 E-005$ & 1 & $5.634 E-005$ & 5.67 & 0.0385 \\
$P^{2}$ & $2.804 E-005$ & 1 & $2.804 E-005$ & 2.82 & 0.1238 \\
$T^{2}$ & $6.470 E-005$ & 1 & $6.470 E-005$ & 6.51 & 0.0287 \\
$C^{2}$ & $3.072 E-005$ & 1 & $3.072 E-005$ & 3.09 & 0.1091 \\
Residual & $9.931 E-005$ & 10 & $9.931 E-005$ & & 0.1808 \\
Lack of fit & $6.999 E-005$ & 5 & $1.400 E-005$ & 2.39 & Not significant \\
Pure error & $2.932 E-005$ & 5 & $5.864 E-005$ & & \\
Cor total & $2.572 E-005$ & 19 & & & \\
\hline
\end{tabular}

In this case $P, T, C, T C$, and $T^{2}$ are significant model terms. Values greater than 0.1000 indicate that the model terms were not significant. If there are many insignificant model terms (not counting those required to support hierarchy), model reduction may improve the model.

The "lack of fit $F$ value" of 2.39 implies that the lack of fit was not significant relative to the pure error. There was an $18.08 \%$ chance that a "lack of fit $F$ value" this large could occur due to noise. Nonsignificant lack of fit is good. The "Pred $R$ Squared" of 0.7763 is in reasonable agreement with the "Adj $R$-Squared" of 0.9266. "Adeq Precision" measures the signal to noise ratio. $P$ ratio greater than 4 is desirable. Our ratio of 21.393 indicates an adequate signal. Each of the observed values compared with the experimental values are shown in Figure 5, and it had a good agreement between the observed values and the experimental values.

\section{Results and Discussion}

4.1. Effect of $p H$ on Corrosion Rate. Figure 6 shows the graph representing the effect of $\mathrm{pH}$ on corrosion rate during salt spray testing and galvanic corrosion testing. For both corrosion tests, the graph shows clearly that the corrosion rate decreased with the increase in $\mathrm{pH}$ value. At every chloride ion concentration and immersion time, the FS welds usually exhibited a decrease in corrosion rate with increase in $\mathrm{pH}$. In neutral $\mathrm{pH}$, the corrosion rate remained approximately constant, and comparatively low corrosion rate was observed in alkaline solution. It was seen that the influence of $\mathrm{pH}$ was more at higher concentration as compared to lower concentration in neutral and alkaline solutions.

On comparing the corrosion rate of both, the corrosion tested specimen was represented as bar diagram in Figure 7. 


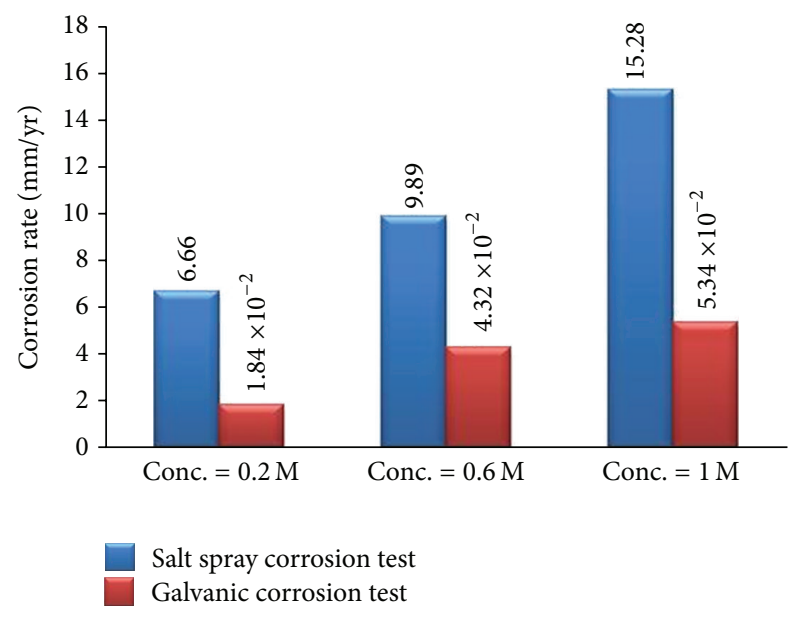

FIgURE 10: Comparative estimation of corrosion rate with respect to chloride ion concentration.

It was found that the corrosion rates obtained from the salt spray testing were much higher than the rates obtained from the galvanic corrosion tests. This was due to spraying effect where recycling of the solution could not be taken into account, while in galvanic corrosion testing; there is a substantial increase in the $\mathrm{pH}$ of the solution during immersion testing causing alkalization or basification of the solution with the increase in reactivity and time. Thus, the corrosion rate was much higher in salt spray testing than in the galvanic corrosion testing. So, the couple were galvanically a good couple, and can be suitable for good applications [20-22].

Figure 8 shows the effect of $\mathrm{pH}$ on pit morphology of the corroded specimen exposed in $0.6 \mathrm{M}$ concentration of $\mathrm{NaCl}$ for 5 hours with different $\mathrm{pH}$ values of $\mathrm{pH} 3, \mathrm{pH}$, and $\mathrm{pH} 11$ for both salt spray testing and galvanic corrosion testing. During salt spray testing, the density of the pit formed in exposing lower $\mathrm{pH}$ (acidic) solution is quite high, compared with the neutral and alkaline solution. It was observed that the matrix shows the pitting marks and the pitting corrosion that has taken place at the friction stir welded microstructure. The particles are $\mathrm{Mn}-\mathrm{Al}$ compound and fragmented $\mathrm{Mg}_{17} \mathrm{Al}_{12}$. The numbers of pits were more in the joints when it is sprayed with the solution of low $\mathrm{pH}$. Hence, the corrosion rate increases with the decrease in $\mathrm{pH}$ value. Since the increase of grain and grain boundary in the joints, the grain boundary acts cathodic to grain causing a microgalvanic effect. The presence of microgalvanic effect between the $\alpha$ phase and the $\beta$ phase that formed was due to the presence of aluminum. During galvanic corrosion tests, the grain boundaries of the anodic specimen got attacked, and its gravity varies with the parameters used in the experiment. Corrosion tends to be concentrated in the area adjacent to the grain boundary until eventually the grain may be undercut and fall out [23].

4.2. Effect of Chloride Ion Concentration on Corrosion Rate. Figure 9 shows the graph representing the effect of chloride ion concentration on corrosion rate during salt spray testing and galvanic corrosion testing. However, it was observed that, with the increase in chloride ion concentration, the rising rate of corrosion rate decreased. The increase in corrosion rate with increasing chloride ion concentration may be attributed to the participation of chloride ions in the dissolution reaction for both corrosion tests [24]. Figure 10 represents the comparison chart for the corrosion rate obtained from both corrosion tests. This is consistent with the detailing of the protective layer. With the increase of chloride ion concentration, the protective layer $\mathrm{Mg}(\mathrm{OH})_{2}$ changed into soluble $\mathrm{MgCl}_{2}$ layer in salt spray corrosion and $\mathrm{Mg}(\mathrm{OH}) \mathrm{Cl}_{2}$ in galvanic corrosion. The corrosion rate was quite higher in salt spray corrosion test than in the galvanic corrosion test. It states that the $\mathrm{MgCl}_{2}$ was highly soluble compared to $\mathrm{Mg}(\mathrm{OH}) \mathrm{Cl}_{2}$.

Figure 11 shows the effect of chloride ion concentration on pit morphology of the corroded specimen exposed in $\mathrm{pH}$ 7 for 5 hours with different chloride ion concentration of $0.2 \mathrm{M}, 0.6 \mathrm{M}$, and $1 \mathrm{M}$ for both salt spray testing and galvanic corrosion testing. During salt spray testing, it showed that the alloy exhibited a rise in corrosion rate with the increase in $\mathrm{Cl}^{-}$concentration and thus, the change of $\mathrm{Cl}^{-}$concentration affected the corrosion rate much more in higher concentration solutions than that in lower concentration solutions. When more $\mathrm{Cl}^{-}$in $\mathrm{NaCl}$ solution promoted the corrosion, the corrosive intermediate $\left(\mathrm{Cl}^{-}\right)$would be rapidly transferred through the outer layer and reache the substrate of the alloy surface. Hence, the corrosion rate increased [20]. But in galvanic corrosion tests, the anodic specimen exhibited a rise in corrosion rate with increase in $\mathrm{Cl}^{-}$concentration and thus, the change of $\mathrm{Cl}^{-}$concentration affected the corrosion rate much more in higher concentration solutions than that in lower concentration solutions. Chloride ions were aggressive for magnesium. The adsorption of chloride ions to oxide covered magnesium surface transformed $\mathrm{Mg}(\mathrm{OH})_{2}$ to easily soluble $\mathrm{MgCl}_{2}$. It was considered that the corrosion becomes severe owing to the penetration of the hydroxide film by $\mathrm{Cl}^{-}$ion and thereby caused the formation of metal hydroxyl chloride complex which governed the following reaction:

$$
\mathrm{Mg}^{2+}+2 \mathrm{H}_{2} \mathrm{O}+2 \mathrm{Cl}^{-} \longrightarrow 2 \mathrm{Mg}(\mathrm{OH})_{2} \mathrm{Cl}_{2}
$$

4.3. Effect of Corrosion Time on Corrosion Rate. Figure 12 shows the graph representing the effect of corrosion time on corrosion rate during salt spray testing and galvanic corrosion testing. During salt spray testing, the graph shows clearly that the corrosion rate was decreased with the increase in exposure time. It resulted in an increase in hydrogen evolution with the increasing exposure time, which tends to increase the concentration of $\mathrm{OH}^{-}$ions strengthening the surface from causing further corrosion. Thus, the rate of corrosion decreases with the increase in corrosion time. During galvanic corrosion testing, the corrosion rate decreases with the increase in immersion time. The increase in immersion time enhanced the tendency to form the corrosion products, which accumulated over the surface of the samples. These corrosion products in turn depressed the corrosion rate due to the passivation in the medium immersion [25]. It resulted in an increase in hydrogen evolution with the increasing 


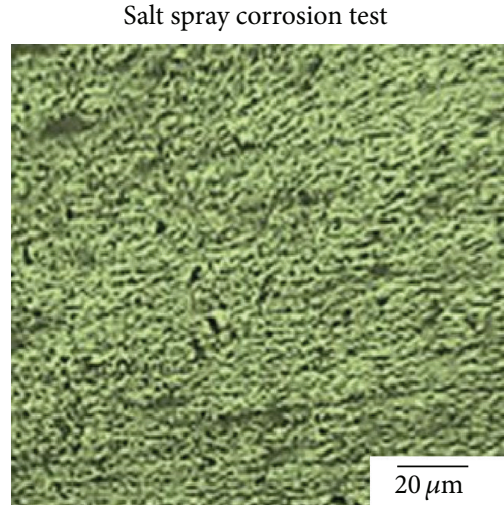

Chloride ion concentration $=0.2 \mathrm{M}$

(a)

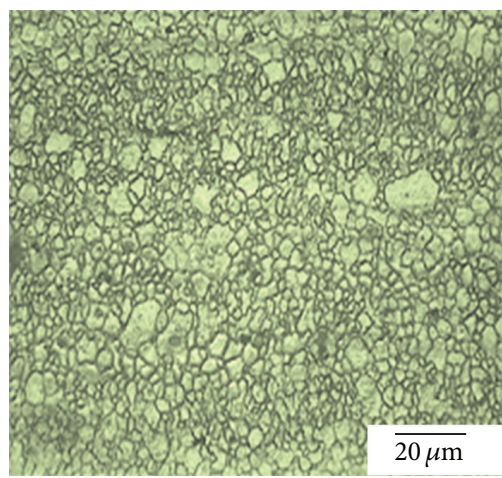

Chloride ion concentration $=0.6 \mathrm{M}$

(c)

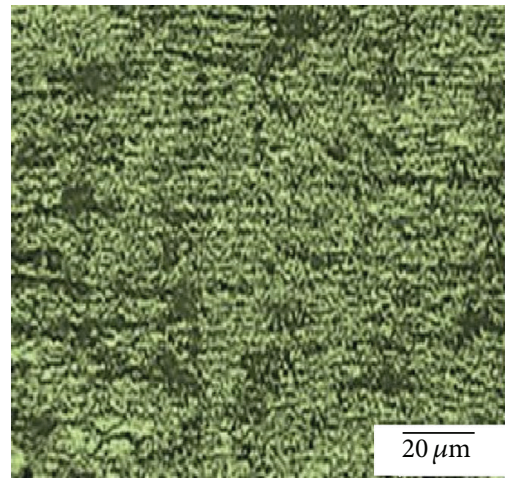

Chloride ion concentration $=1 \mathrm{M}$

(e)

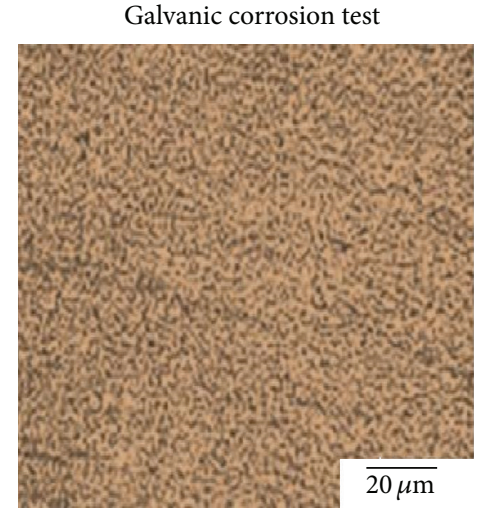

Chloride ion concentration $=0.2 \mathrm{M}$

(b)

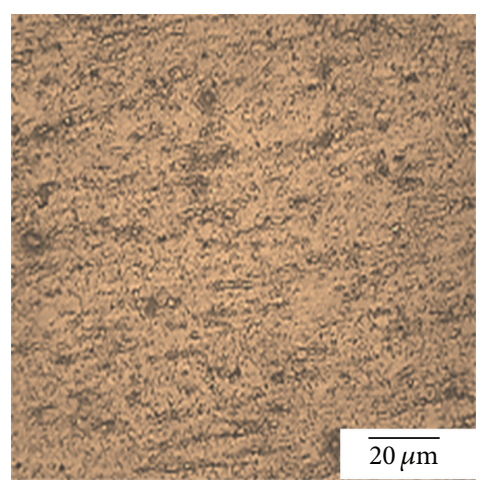

Chloride ion concentration $=0.6 \mathrm{M}$

(d)

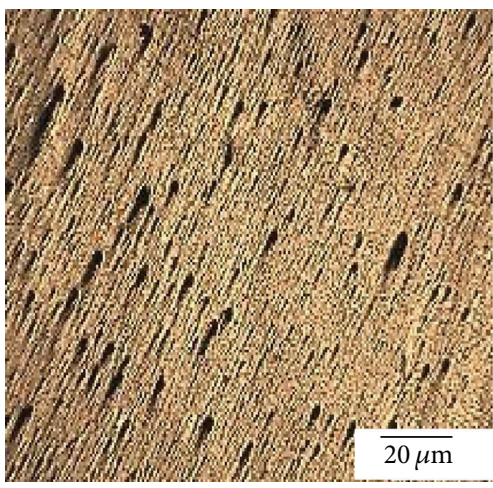

Chloride ion concentration $=1 \mathrm{M}$

(f)

FIGURE 11: Effect of chloride ion concentration on pit morphology.

immersion time, which tends to increase the concentration of $\mathrm{OH}^{-}$ions strengthening the surface from causing further corrosion. The strength of the electrolyte reduces from acidity to alkalinity with the increase of time.

This is attributed to corrosion occurs over an increasing fraction on the surface leaving the white flakes, which is the insoluble corrosion product [24]. The insoluble corrosion products on the surface of the alloy could slow down the corrosion rate:

$$
\mathrm{Mg} \longrightarrow \mathrm{Mg}^{2+}+2 \mathrm{e}^{-}
$$

$$
\begin{aligned}
& 2 \mathrm{H}_{2} \mathrm{O}+2 \mathrm{e}^{-} \longrightarrow 2 \mathrm{OH}^{-}+\mathrm{H}_{2} \\
& \mathrm{Mg}^{2+}+2 \mathrm{OH}^{-} \longrightarrow \mathrm{Mg}(\mathrm{OH})_{2}
\end{aligned}
$$

Figure 13 shows the comparison of the corrosion rate obtained during the salt spray and galvanic corrosion test. With the increase of corrosion time the corrosion rate decreases for both specimens. It proved that the protective layer made a predominant role to strike against corrosion with the increment of time. The corrosion rate seems higher in salt spray corrosion test due to the spraying effect, while 


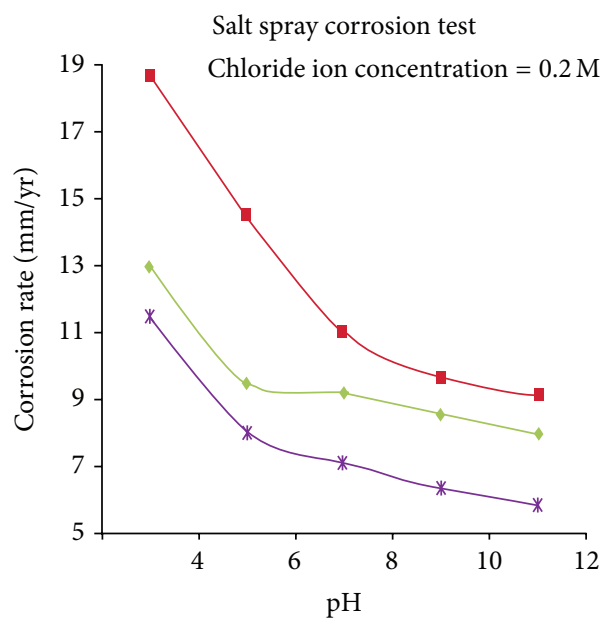

(a)

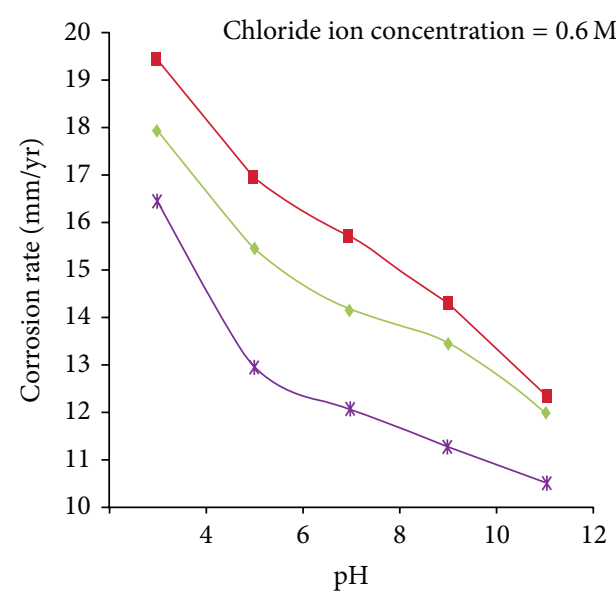

(c)

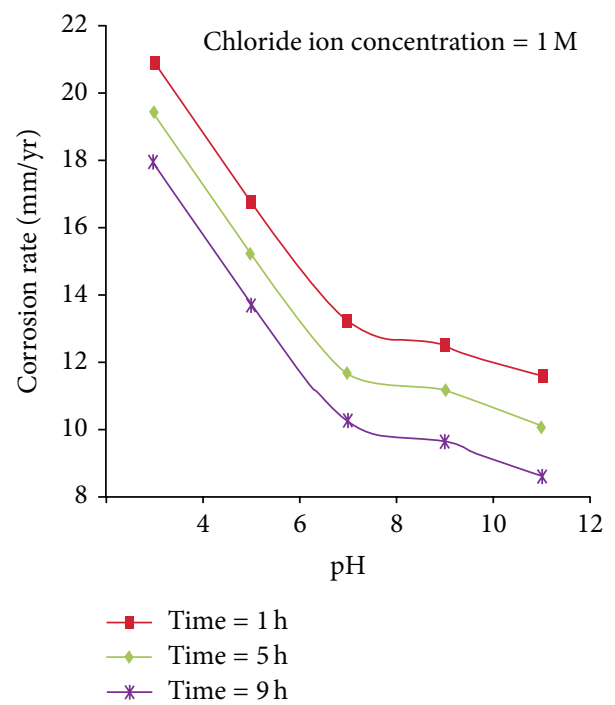

(e)

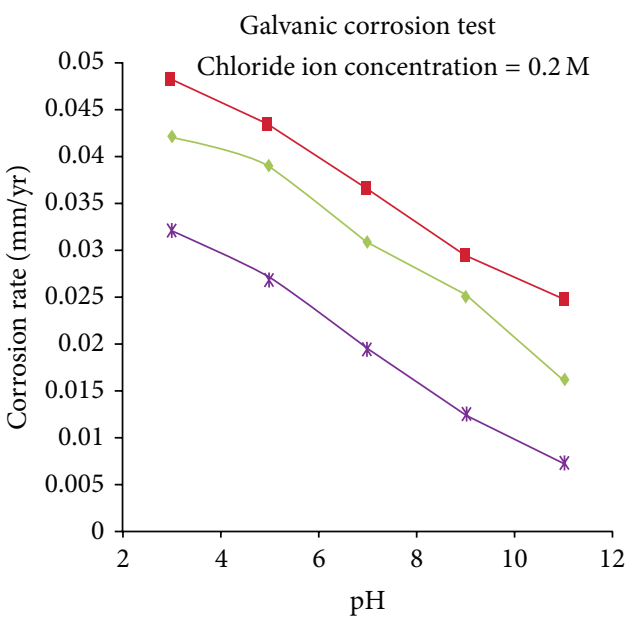

(b)

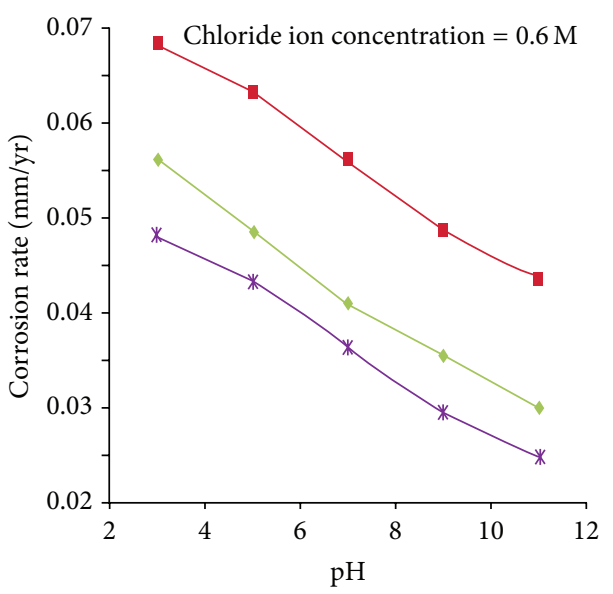

(d)

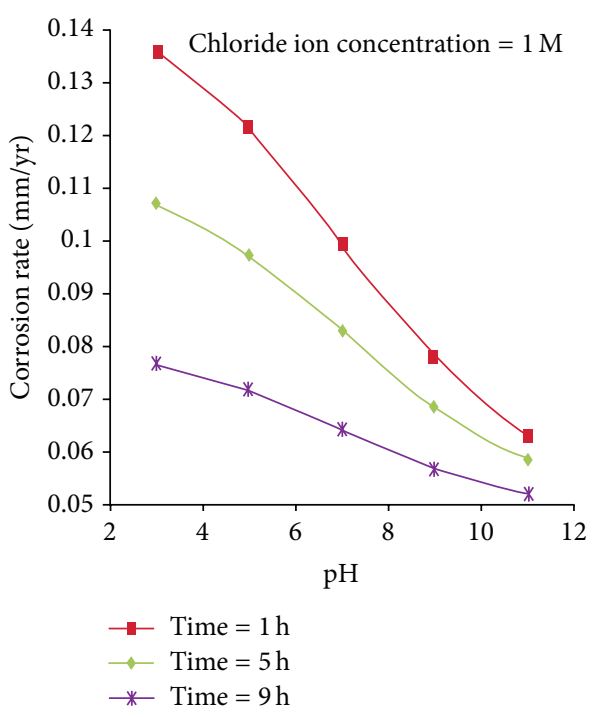

(f)

FIGURE 12: Effect of corrosion time on corrosion rate. 


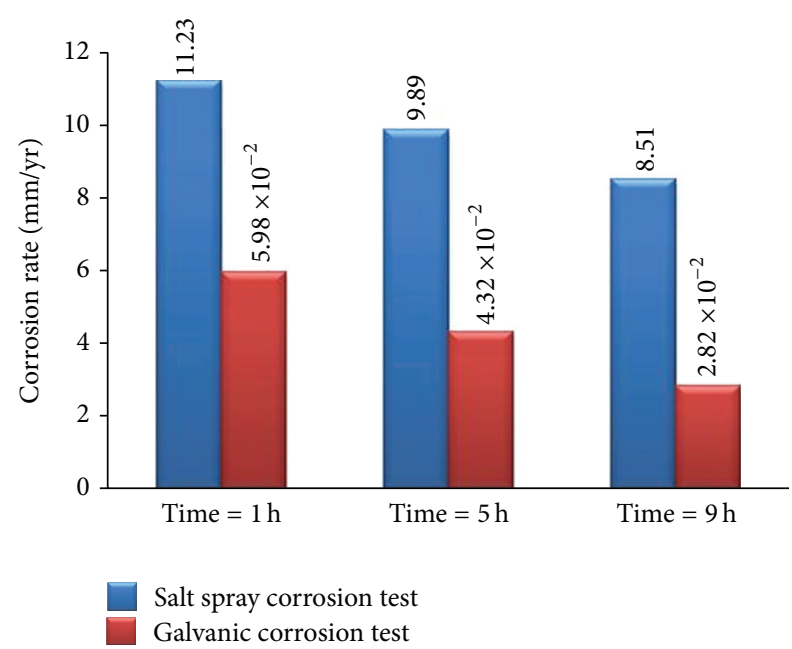

FIGURE 13: Comparative estimation of corrosion rate with respect to corrosion time.

in immersed condition, the protective layer formed during galvanic corrosion was enhanced by the alkalization of the solution.

Figure 14 shows the effect of corrosion time on pit morphology of the corroded specimen exposed in $\mathrm{pH} 7$ with chloride ion concentration of $0.6 \mathrm{M} \mathrm{NaCl}$ exposed, $1 \mathrm{~h}, 5 \mathrm{~h}$, and $9 \mathrm{~h}$ for both salt spray testing and galvanic corrosion testing. The mode of microstructural features was comparatively the same during corrosion testing for both tests as its corrosion time is taken into account. The FS welded specimens possess refined grain, and quite a lot of $\beta$ particles were distributed continually along the grain boundary.

In this case, $\beta$ phase particles cannot be easily destroyed and, with the increase of corrosion time, the quantity of $\beta$ phases in the exposed surface would increase and finally play the role of corrosion barrier [26]. Although there are some grains of $\alpha$ phase still being corroded, most of the remaining $\alpha$ phase grains are protected under the $\beta$ phase barrier, so the corrosion rate decreased with the increase in corrosion time. Thus, the corrosion morphology of the alloy was predominantly controlled by the $\beta$ phase distribution [27].

4.4. SEM and XRD Analysis. Figure 15 shows the surface texture of the specimens that underwent salt spray corrosion and galvanic corrosion tests which were observed under SEM as corrosion time was a factor. Figure 15(a) shows the specimens exposed to 1 hour comprised of more localized attack. With corrosion time as a factor, the less spraying time tends to attack more locally on the surface, and later, it penetrates to the substrates, causing higher corrosion behavior and corrosion rate. It was redeems to spalling of corrosion products. Thus, serious pitting occurred in the surface of the weldment with less exposure time for both corrosion-tested specimens. The quantity of corrosion products formed was quite comparably larger in the galvanic corrosion test caused due to immersion.

Figure 15(b) shows the specimens exposed to 9 hours composed of more corrosion products. With the increase in corrosion time, the hydroxide layer formed is the dominant factor to avoid further corrosion. This is attributed to corrosion occurring over an increasing fraction of the surface, which is the insoluble corrosion product, $\mathrm{Mg}(\mathrm{OH})_{2}$. Thus, the corrosion rate decreases with the increase of corrosion time. It was observed that the corrosion products were thick and adherent in the specimen that underwent galvanic corrosion test while the specimen that underwent salt spray test exhibited lamellar corrosion products, which seems higher attack and less protective. This showed higher corrosion rate in the salt spray test than the galvanic corrosion test.

Figure 16 shows the XRD analysis to predict the composition of corrosion products and phase in the specimen subjected to salt spray and galvanic corrosion tests. Figure 16(a) shows that the specimen underwent the salt spray corrosion test; the characteristic peaks originate from the metallic $\mathrm{Mg}$ substrate and the $\beta$ phase. The detected number of peaks relates to the $\beta$ phase $\left(\mathrm{Mg}_{17} \mathrm{Al}_{12}\right)$ which is higher in its intensities. It symbolizes the hydroxide layer which finds it hard to form during the salt spray corrosion test due to its spraying effects. However, $\mathrm{Mg}(\mathrm{OH})_{2}$ and $\mathrm{MgO}$ phases are detected in Figure 16(b), where the specimen underwent the galvanic corrosion test; $\mathrm{Mg}(\mathrm{OH})_{2}$ is the dominant product in the corrosion zone of the anodic specimen that underwent the galvanic corrosion test. $\mathrm{Mg}(\mathrm{OH})_{2}$ (brucite) has a hexagonal crystal structure and easily undergoes basal cleavage causing cracking and curling in the film, which could play a major role in reducing the corrosion behavior and the corrosion rate. It signifies during immersion that the alkalization effect tends to strengthen the formation of the hydroxide layer.

\section{Conclusions}

(1) A mathematical model has been developed here to predict the corrosion rate using salt spray tests and galvanic corrosion with a $95 \%$ confidence level. The corrosion rates obtained were quite different in both tests; it found that, the corrosion rate was much higher in salt spray test than in the galvanic corrosion test.

(2) In this investigation, it was proved from both tests, for every $\mathrm{pH}$ value; that the FS weld metal exhibited a rise in corrosion rate with decrease in $\mathrm{pH}$ value. In the neutral $\mathrm{pH}$, the corrosion rate remained approximately constant in neutral solutions, and a comparatively low corrosion rate was observed in alkaline solutions.

(3) Chloride ions were aggressive on magnesium alloy. The adsorption of chloride ions to oxide covered the magnesium surface and transformed $\mathrm{Mg}(\mathrm{OH})_{2}$ to easily soluble $\mathrm{MgCl}_{2}$ in salt spray corrosion testing while in galvanic corrosion testing, it readily formed $\mathrm{Mg}(\mathrm{OH})_{2} \mathrm{Cl}_{2}$ due to the immersion criterion.

(4) It resulted in an increase in hydrogen evolution with the increasing corrosion time, which tended to increase the concentration of $\mathrm{OH}^{-}$ions; thereby, an increasing fraction of the surface was observed, which is the insoluble corrosion products. The insoluble 


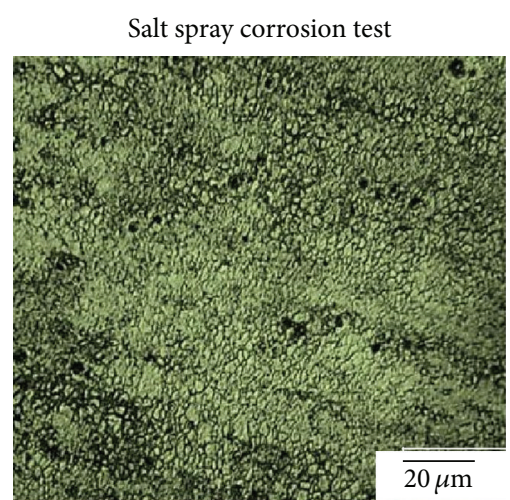

Corrosion time $=1 \mathrm{~h}$

(a)

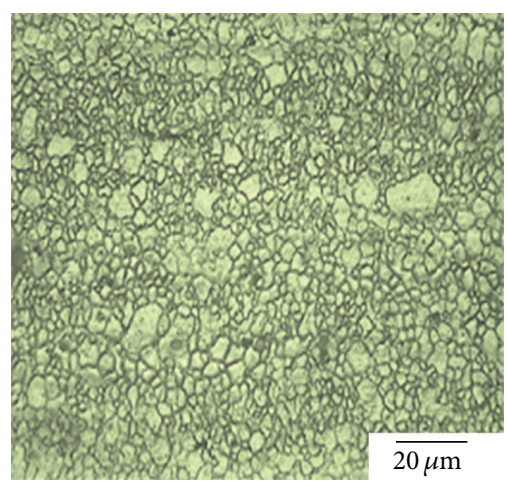

Corrosion time $=5 \mathrm{~h}$

(c)

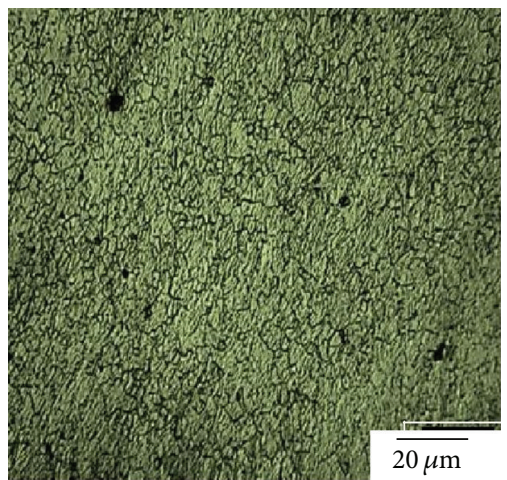

Corrosion time $=9 \mathrm{~h}$

(e)

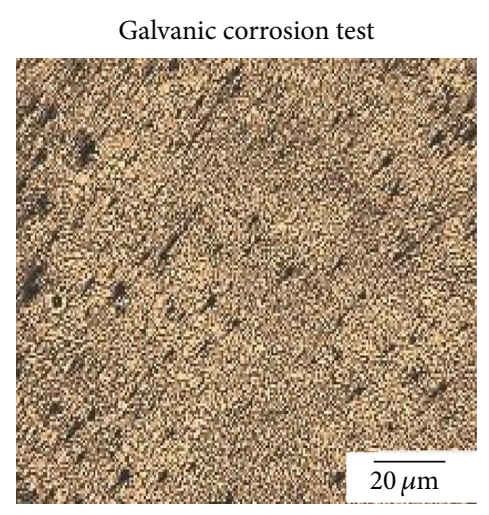

Corrosion time $=1 \mathrm{~h}$

(b)

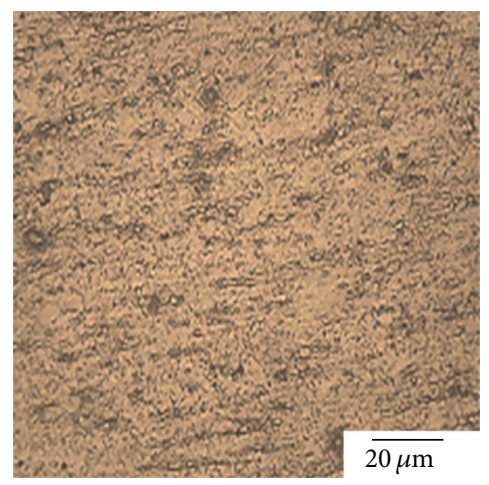

Corrosion time $=5 \mathrm{~h}$

(d)

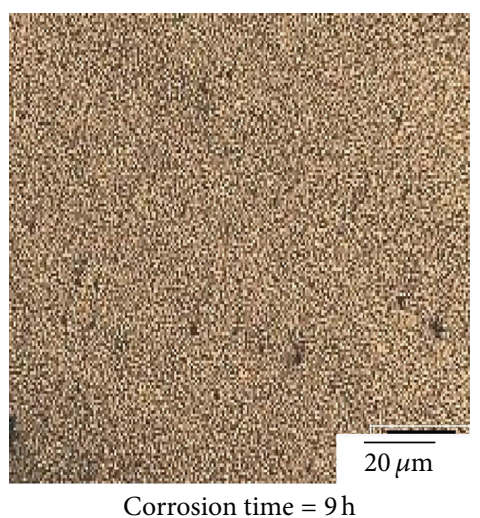

(f)

FIGURE 14: Effect of corrosion time on pit morphology.

corrosion products on the surface of the alloy could slow down the corrosion rate.

(5) In this investigation, it was found that the corrosion rate obtained from the salt spray tests was much higher than the rates obtained from the galvanic corrosion tests. It was due to spraying effect where stagnation of the solution could not be taken into account while in galvanic corrosion testing, there is a substantial increase in the $\mathrm{pH}$ of the solution during corrosion reactions due to the migration of ions in the electrolyte under immersion. The corrosion rate of galvanic couple ranges from 0.03 to $0.06 \mathrm{~mm} / \mathrm{yr}$, which is quite negligible, and shows excellent property of corrosion resistant as per corrosion handbooks and guides. So, the couple were galvanically a good couple, and they can be suitable for good applications.

\section{Conflict of Interests}

The authors declare that there is no conflict of interests. 
Salt spray corrosion test

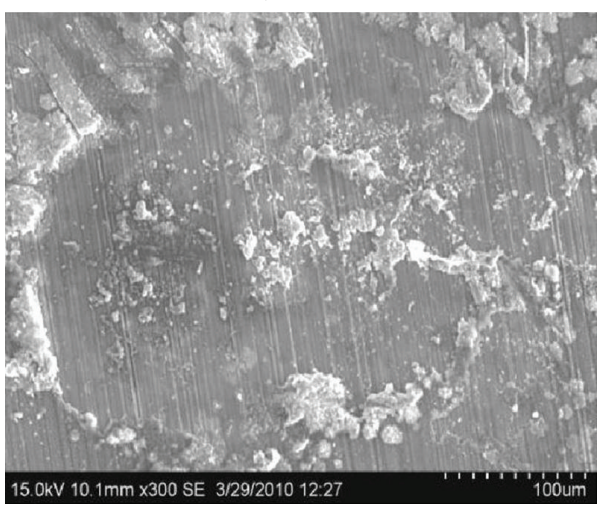

Galvanic corrosion test

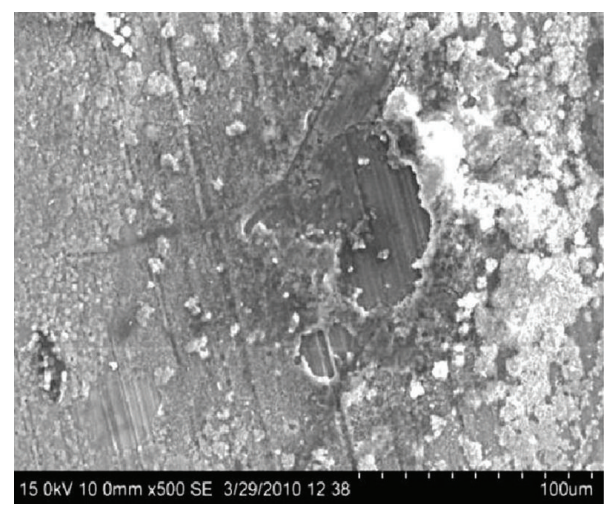

(15 akv 10 anm $x$
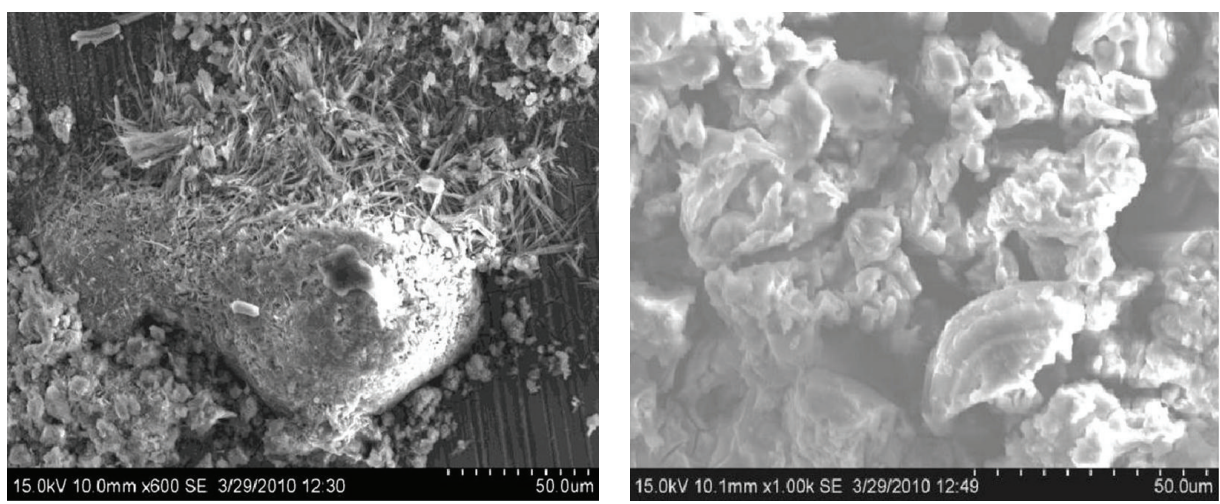

(b) Corrosion time $=9 \mathrm{~h}$

FIGURE 15: Scanning electron micrograph of corrosion test specimens underwent salt spray corrosion test and galvanic corrosion test.
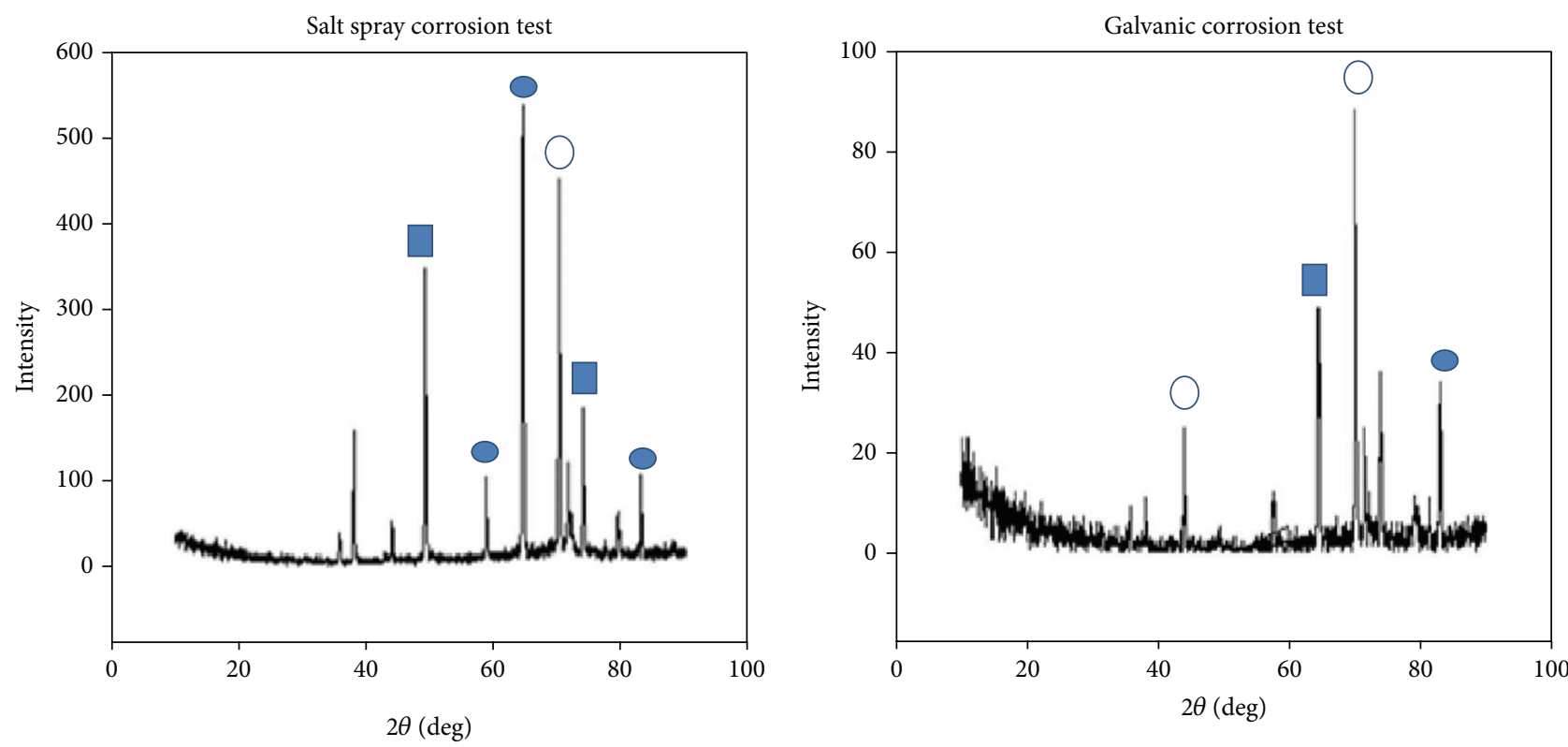

$\mathrm{Mg}$

$\mathrm{Mg}(\mathrm{OH})_{2}$

$\mathrm{Mg}_{17} \mathrm{Al}_{12}$

(a)

(b)

FIGURE 16: XRD pattern of corrosion test specimens underwent salt spray corrosion test and galvanic corrosion test. 


\section{Acknowledgment}

The authors would like to thank the Centre for Materials Joining \& Research (CEMAJOR), Department of Manufacturing Engineering, Annamalai University, Annamalai Nagar, India for extending the facilities of Materials Joining Laboratory and Corrosion Testing Laboratory to carry out this investigation.

\section{References}

[1] B. L. Mordike and T. Ebert, "Magnesium Properties, applications, potential," Materials Science and Engineering A, vol. 302, no. 1, pp. 37-45, 2001.

[2] R. C. Zeng, W. Dietzel, R. Zettler, J. Chen, and K. U. Kainer, "Microstructure evolution and tensile properties of frictionstir-welded AM50 magnesium alloy," Transactions of Nonferrous Metals Society of China, vol. 18, no. 1, pp. s76-s80, 2008.

[3] R. C. Zeng, J. Zhang, W. J. Huang et al., "Review of studies on corrosion of magnesium alloys," Transactions of Nonferrous Metals Society of China, vol. 16, supplement 2, pp. s763-s771, 2006.

[4] T. Nagasawa, M. Otsuka, T. Yokota, and T. Ueki, "Structure and mechanical properties of friction stir weld Joints of magnesium alloy AZ31," in Magnesium Technology 2000, H. I. Kaplan, J. Hryn, and B. Clow, Eds., pp. 383-387, TMS, Warrendale, Pa, USA, 2000.

[5] W. Xu, J. Liu, and H. Zhu, "Pitting corrosion of friction stir welded aluminum alloy thick plate in alkaline chloride solution," Electrochimica Acta, vol. 55, no. 8, pp. 2918-2923, 2010.

[6] M. Zhao, S. Wu, J. R. Luo, Y. Fukuda, and H. Nakae, "A chromium-free conversion coating of magnesium alloy by a phosphatepermanganate solution," Surface and Coatings Technology, vol. 200, no. 18-19, pp. 5407-5412, 2006.

[7] B. A. Shaw, "Corrosion resistance of magnesium alloys," in ASM Handbook, vol. 13A: Corrosion, L. J. Korb, Ed., p. 692, ASM International Handbook Committee, Metals Park, Ohio, USA, 9th edition, 2003.

[8] D. L. Hawke, J. E. Hillis, M. pekguleryuz, and I. Nkatusugawa, "Corrosion behavior," in Magnesium and Magnesium Alloys, M. M. Avedesian and H. Baker, Eds., pp. 194-1210, ASM International, Materials Park, Ohio, USA, 1999.

[9] G. Song and A. Atrens, "Recent insights into the mechanism of magnesium corrosion and research suggestions," Advanced Engineering Materials, vol. 9, no. 3, pp. 177-183, 2007.

[10] G. Song, B. Johanesson, S. Hagupoda, and D. StJohn, "Galvanic corrosion of magnesium alloy AZ91D in contact with an aluminium alloy, steel and zinc," Corrosion Science, vol. 46, no. 4, pp. 955-977, 2004.

[11] M. Jönsson, D. Persson, and D. Thierry, "Corrosion product formation during $\mathrm{NaCl}$ induced atmospheric corrosion of magnesium alloy AZ91D," Corrosion Science, vol. 49, no. 3, pp. 1540-1558, 2007.

[12] R. G. Song, C. Blawert, W. Dietzel, and A. Atrens, "A study on stress corrosion cracking and hydrogen embrittlement of AZ31 magnesium alloy," Materials Science and Engineering A, vol. 399, no. 1-2, pp. 308-317, 2005.

[13] M. B. Kannan, W. Dietzel, C. Blawert, S. Riekehr, and M. Koçak, "Stress corrosion cracking behavior of Nd:YAG laser butt welded AZ31 Mg sheet," Materials Science and Engineering A, vol. 444, no. 1-2, pp. 220-226, 2007.
[14] R. Baboian, "Electrochemical techniques for corrosion engineering," in Corrosion '76, p. 114, NACE, 1976.

[15] H. Altun and S. Sen, "Studies on the influence of chloride ion concentration and $\mathrm{pH}$ on the corrosion and electrochemical behaviour of AZ63 magnesium alloy," Materials and Design, vol. 25, no. 7, pp. 637-643, 2004.

[16] Y. Song, D. Shan, R. Chen, and E. H. Han, "Effect of second phases on the corrosion behaviour of wrought $\mathrm{Mg}-\mathrm{Zn}-\mathrm{Y}-\mathrm{Zr}$ alloy," Corrosion Science, vol. 52, no. 5, pp. 1830-1837, 2010.

[17] K. H. Goh, T. T. Lim, and P. C. Chui, "Evaluation of the effect of dosage, $\mathrm{pH}$ and contact time on high-dose phosphate inhibition for copper corrosion control using response surface methodology (RSM)," Corrosion Science, vol. 50, no. 4, pp. 918927, 2008.

[18] N. Aslan, "Application of response surface methodology and central composite rotatable design for modeling and optimization of a multi-gravity separator for chromite concentration," Powder Technology, vol. 185, no. 1, pp. 80-86, 2008.

[19] J. S. Cowpe, J. S. Astin, R. D. Pilkington, and A. E. Hill, "Application of response surface methodology to laser-induced breakdown spectroscopy: Influences of hardware configuration," Spectrochimica Acta B, vol. 62, no. 12, pp. 1335-1342, 2007.

[20] A. Dhanapal, S. R. Boopathy, and V. Balasubramanian, "Developing an empirical relationship to predict the corrosion rate of friction stir welded AZ61A magnesium alloy under salt fog environment," Materials and Design, vol. 32 , no. 10, pp. 50665072, 2011.

[21] B. D. Craig and D. B. Anderson, Handbook of Corrosion Data, ASM International, 1995.

[22] H. H. Uhlig, The Corrosion Handbook, John Wiley, 1948.

[23] N. Hara, Y. Kobayashi, D. Kagaya, and N. Akao, "Formation and breakdown of surface films on magnesium and its alloys in aqueous solutions," Corrosion Science, vol. 49, no. 1, pp. 166-175, 2007.

[24] G. Song, A. Atrens, and M. Dargusch, "Influence of microstructure on the corrosion of diecast AZ91D," Corrosion Science, vol. 41, no. 2, pp. 249-273, 1998.

[25] Z. M. Zhang, H. Y. Xu, and B. C. Li, "Corrosion properties of plastically deformed AZ80 magnesium alloy," Transactions of Nonferrous Metals Society of China, vol. 20, no. 2, pp. s697-s702, 2010.

[26] Y. Song, D. Shan, R. Chen, and E. H. Han, "Effect of second phases on the corrosion behaviour of wrought $\mathrm{Mg}-\mathrm{Zn}-\mathrm{Y}-\mathrm{Zr}$ alloy," Corrosion Science, vol. 52, no. 5, pp. 1830-1837, 2010.

[27] Corrosion Tests and Standards: Application and Interpretation, ASTM international, 2005. 

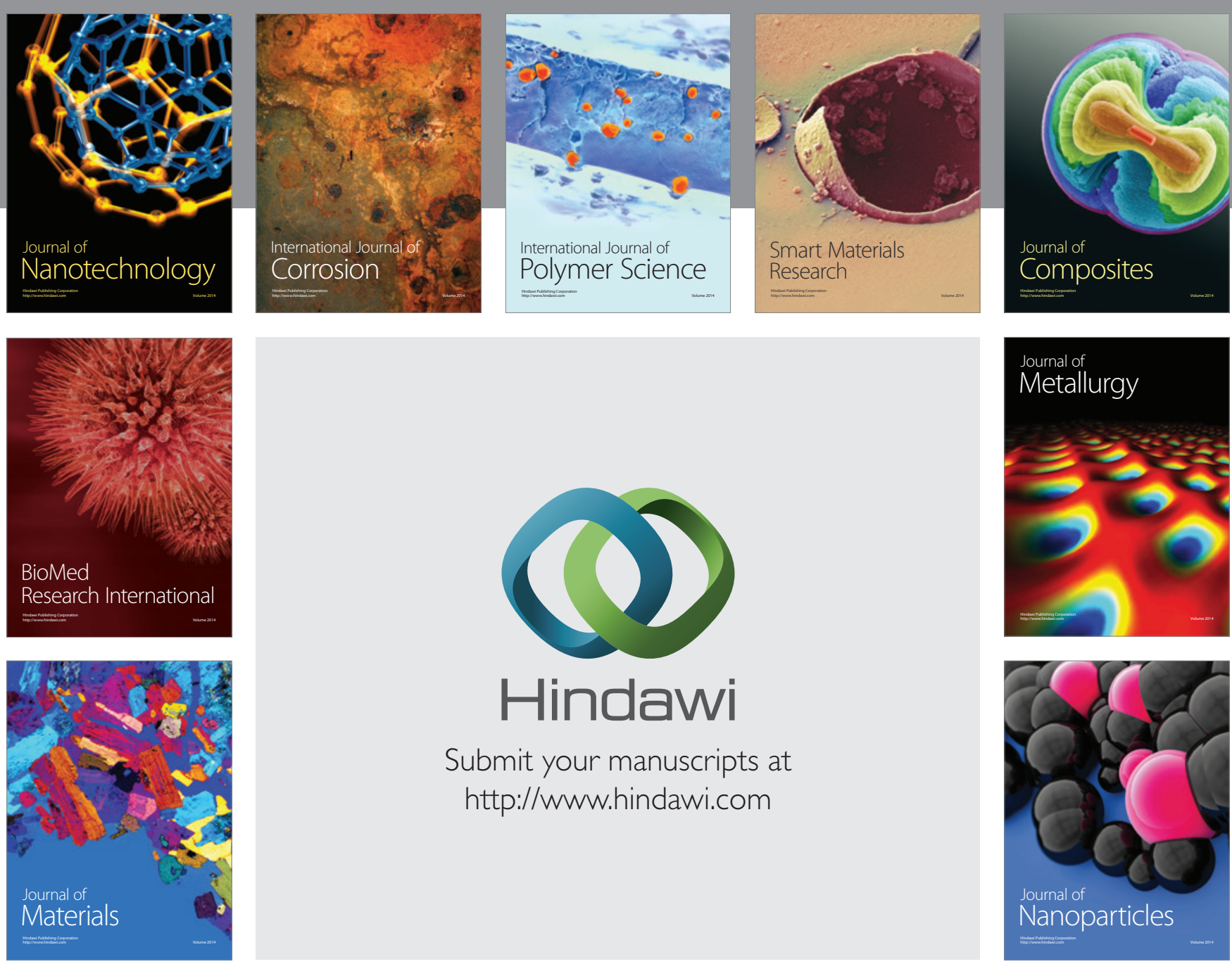

Submit your manuscripts at http://www.hindawi.com
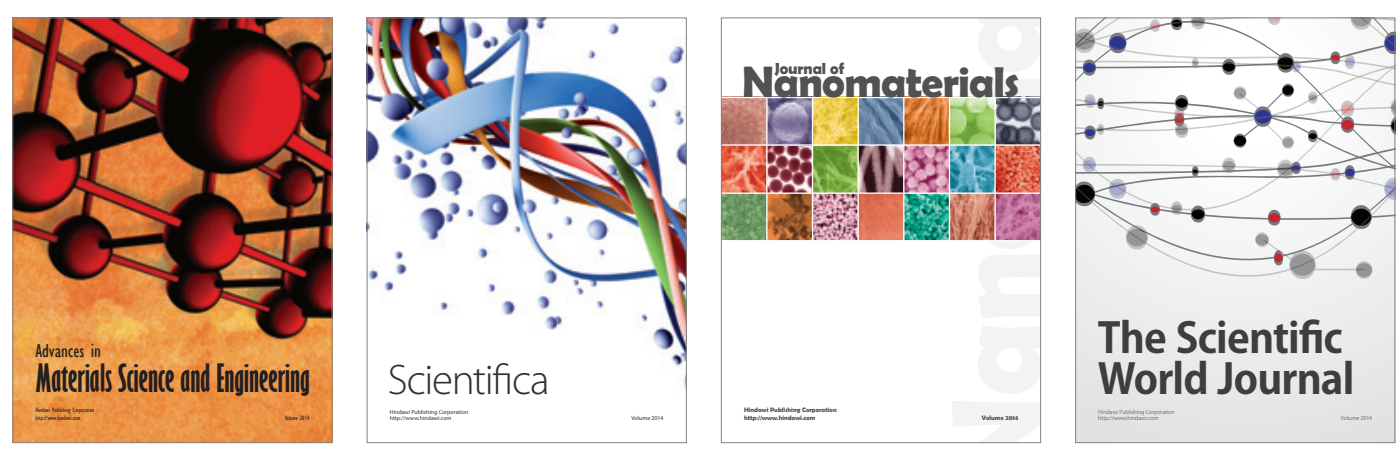

\section{The Scientific World Journal}
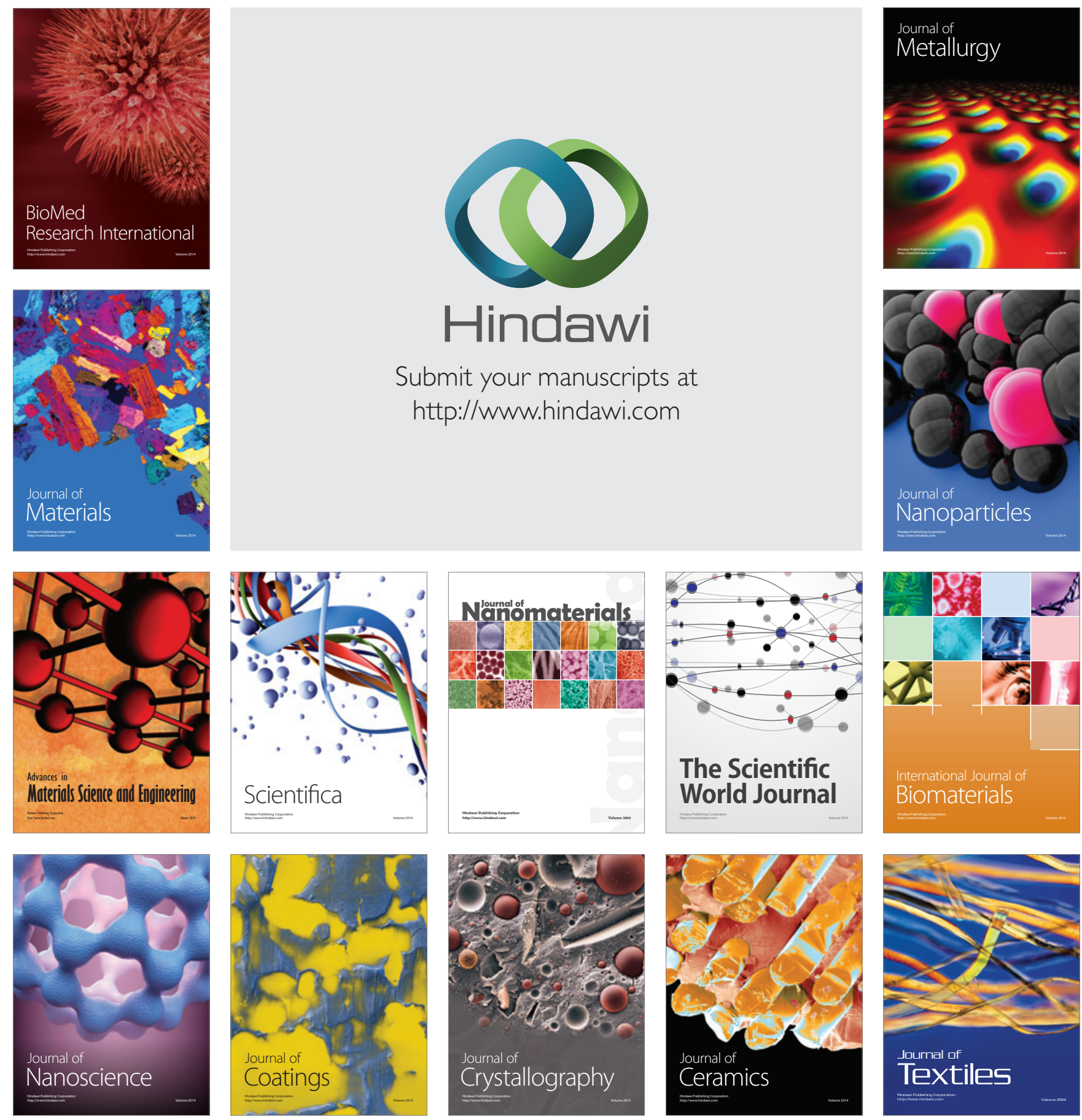